\title{
Research on Crop Growing Factory: Focusing on Lighting and Environmental Control with Technological Proposal
}

\author{
Ki-Youn Kim ${ }^{1}$, Jun-Ho Huh ${ }^{2}$ and Han-Jong Ko ${ }^{3, *(D)}$ \\ 1 Department of Safety Engineering, Seoul National University of Science and Technology, Seoul 01811, Korea; \\ kky5@seoultech.ac.kr \\ 2 Department of Data Science, (National) Korea Maritime and Ocean University, Busan 600-011, Korea; \\ 72networks@kmou.ac.kr \\ 3 Department of Agricultural Sciences, Korea National Open University, Seoul 03087, Korea \\ * Correspondence: khjong333@knou.ac.kr; Tel.: +82-2-3668-4633
}

check for updates

Citation: Kim, K.-Y.; Huh, J.-H.; Ko, H.-J. Research on Crop Growing Factory: Focusing on Lighting and Environmental Control with Technological Proposal. Energies 2021, 14, 2624. https://doi.org/10.3390/ en14092624

Academic Editor: Luigi Pari

Received: 7 February 2021

Accepted: 13 April 2021

Published: 3 May 2021

Publisher's Note: MDPI stays neutral with regard to jurisdictional claims in published maps and institutional affiliations.

Copyright: (c) 2021 by the authors. Licensee MDPI, Basel, Switzerland. This article is an open access article distributed under the terms and conditions of the Creative Commons Attribution (CC BY) license (https:// creativecommons.org/licenses/by/ $4.0 /)$.

\begin{abstract}
Recently, the interest in the plant factory-based crop production technologies is rising following the application of the smart farm technology to the agricultural arena. A lettuce production system platform is proposed in this study considering the effects of indoor environmental conditions and artificial light sources. The spectral characteristics of a visible ray according to growth performances were analyzed first to develop a control algorithm that can stimulate the plant's growth for the proposal. Secondly, an imaging system was designed to analyze the plant's growth characteristics based on the images and set up the system configuration. Lastly, a crop production system was proposed by using an experimental crop production group for environmental control and monitoring.
\end{abstract}

Keywords: plant factory; lettuce; particulate pollutant; wavelength; smart farm; smart LED farm; smart LED farm algorithm; IoT energies; LED energies

\section{Introduction}

The modern dietary habit of pursuing wellbeing remarkably increased the consumption of leafy vegetables and fruits by 30\% between 1980 and 1990, and by $56 \%$ between 1990 and 2003 [1]. Among the crops falling under these categories, there are many that are high value-added crops [2]. Nonetheless, these crops need to adjust well to environmental conditions, since the product value and growth development are being changed under different environments [3].

In particular, lettuce has many varieties, the representative types being romaine, butterhead, loose-leaf, and crisphead. Among loose-leaf vegetables, red chrysanthemum cultivars are the most favored vegetables by Korean consumers, as an indispensable item on their dining table. However, the storage performance of lettuce is very poor, and it cannot keep up with consumer demand. This perishable nature of lettuce is well-known $[4,5]$. Therefore, survey results showed that there are several crop items grown in the vicinity of large cities, so outgoing transportation to the market, where purchases are made by customers, does not take a longer lead time [6,7].

When growing leafy vegetables in the factory, temperature and humidity are important factors [8-10].

Moreover, these crops are sensitive to the concentration of particulate pollutants, as well as airborne microorganisms that feed on particular pollutants [11-15]. Specifically, some of the airborne microorganisms contain pathogens for crop items, which cause diseases in the crops [16-18].

Since these are not visible to the naked eye, if we do not have professional knowledge in controlling the crops, we are unable to do anything but watch the crops become damaged. For these sensitive crops, the factory has been introduced for the first time, and cultivation 
was performed by conducting research on seedling vegetables that grew under highpressure sodium lamps by the Christensen Farm, Denmark, in 1957 [19-22].

Since crops are grown indoors to create a pleasant environment where temperature, humidity, particulate pollutants, and airborne microorganisms are controlled, rather than in an ordinary outdoor field, additional costs and management are also required to maintain such an environment [23-25].

Therefore, there is a need for research investigating the environmental elements inside plants, but theses and reports related to this are almost nonexistent. In this study, the elements of environmental conditions in a factory were investigated to monitor the effects of environmental conditions on lettuce, as well as the growth characteristics of lettuce.

The various factors caused by environmental conditions inside the plant factory were investigated, and site monitoring was conducted to examine the effect of indoor air quality and different light sources on the growth of lettuce.

Also, the analysis result shows that the techniques that arithmetically use reflection properties in visible light and Near-InfraRed (NIR) area have a closer relationship with biomess, compared to the techniques that separately use visible lights or NIR. Thus, this imaging system was designed to perform monitoring, according to the crop's condition, by selecting appropriate filters for individual crops and by using the converged image obtained by using these filters. An NIR filter was designed to indicate the growth condition of crops, according to their characteristics, along with a filter wheel containing four channels, on which red, green, and blue filters can be installed. The filter wheel uses a small servomotor and is operated by using a single-chip microprocessor. The images acquired through filters are processes by the NIR-Enhanced Monochrome Charged-Coupled Device (CCD) camera, controlled by the PC (Personal Computer), and the motor driven by the microprocessor was designed to be synchronized with the image signals, controlled by the PC.

\section{Related Research}

The plant factory in a smart farm allows for planned production throughout the year as it can control the environmental factors such as temperature, light or $\mathrm{CO}_{2}$ according to the level of the plant's growth [26,27]. The plant factories can be classified by how the light(s) is supplied and the typical ones are a solar type, LED type, or a solar-LED combined type. In the major of IT, some of the previous studies that focused on the plant factories are as follows: "A Research on Plant Factory Automation System" [28], "The Growth Performances of Light-Emitting Diode Lighting on Greenhouse Plant Growth and Quality" [29], and "Production of Leaf Vegetables Using LED Light Source" [30].

Also, there was a test result that the growth of lettuce or kale was stimulated when anionic treatment had been applied.

Following the increase in the volume of vegetables used for wrapping food, consumers desire top-quality and safe leaf vegetables rich in functional substances; as such, a proper environmental management that satisfies both high productivity and quality is required. One of the most important factors in environmental control is light management technology but the yield or growth plants in every factory using either LEDs or fluorescent lights can be varied as the intensity or quality of light is different from the solar rays. The sunlight is usually drawn into the production area through optical pipelines or fibers.

Currently, a soilless production system is being adopted by many plant factories using some kinds of artificial lighting systems [31]. Depending on the plant types, some sort of a medium that replaces the soil is necessary and it should be able to supply appropriate physicochemical and biological substances in the process of seeding and managing stages to provide a better rooting environment [32]. One of the popular such mediums is peat which is a dark brown substance similar to soil that was formed and accumulated over a long period time by dying plants or vegetation including mosses and has been preferred for its affordability and availability, as well as fine functionality [33,34].

Despite these merits, there are concerns about its excessive use and production process, so it may not be available in the future as much as it is today [35-37]. Although a variety of 
alternative materials (Coir pith, wood fiber, composted materials, biochar, etc.) are being sought and introduced in the market [32,34,38-42], none of them has yet replaced peat as long as functionality and cost are concerned; still, such an attempt may open up the way of developing an alternative solution that utilizes peat in combination with other materials that can be recycled [33], considering ever increasing demand for the plant production mediums due to rapid global population growth $[43,44]$.

\section{Methods and Proposed System}

The representing prototype has been upgraded from $\mathrm{a}, \mathrm{b}$ and then to $\mathrm{c}$ going through each stage of respective operation processes. First, in Figure 1, a is the 1st generation plant developed in early stages of development and controls the factors such as temperature, humidity, and $\mathrm{CO}_{2}$ only by adjusting lighting and ventilation [45], whereas $\mathrm{b}$ is the 2nd generation plant to which Information and Communications Technology (ICT) has been applied to create a proper lettuce growing environment by controlling indoor air quality through the operation of an air purifier [46]. Based on the system developed in this study, an Internet of Things (IoT)-applied plant factory (3rd generation) that monitors the lettuce growing process through Closed-Circuit Television (CCTV) operation and indoor air quality control is proposed [47]. It is expected that such a factory will outperform the others in terms of functionality.

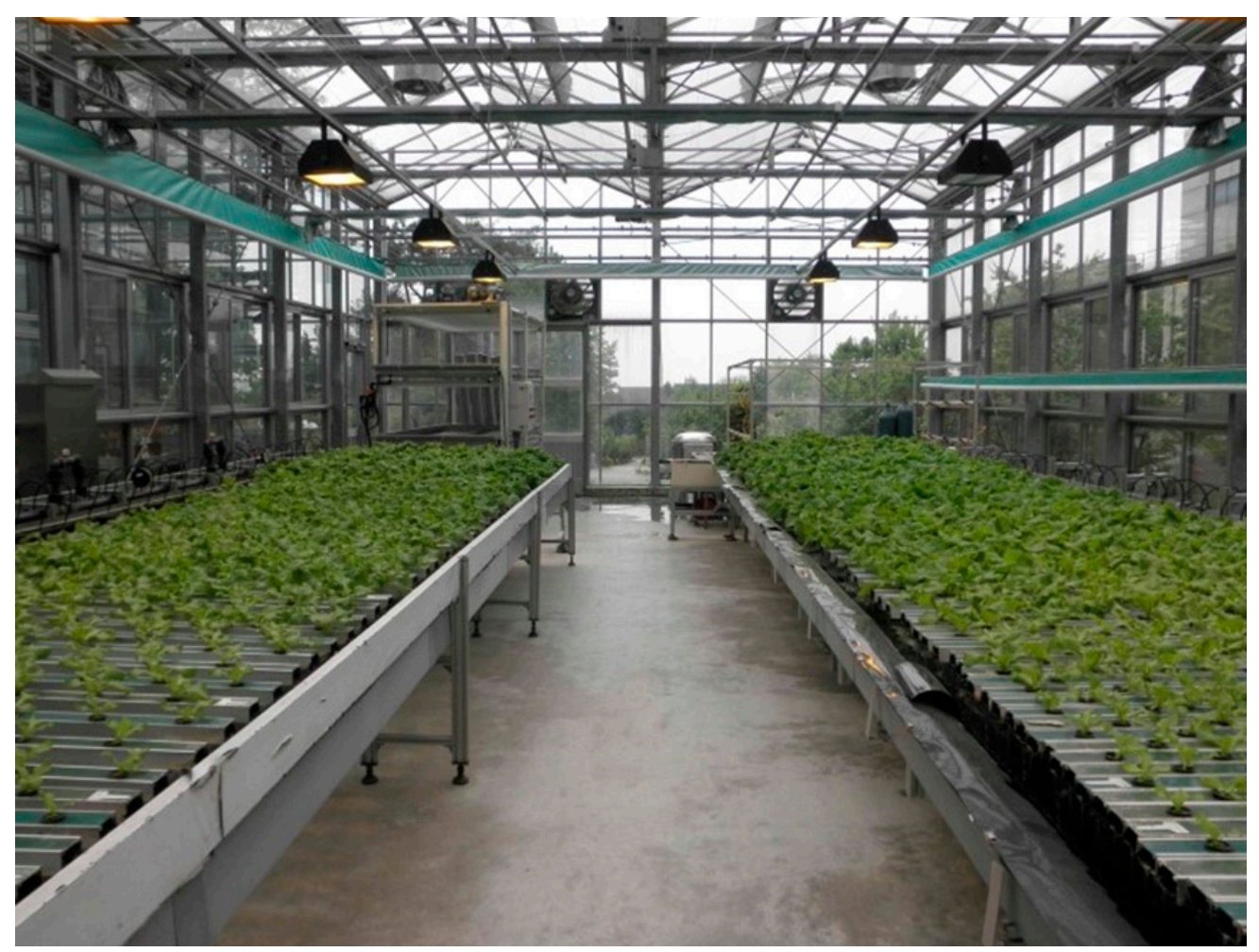

(a) 1st generation

Figure 1. Cont. 


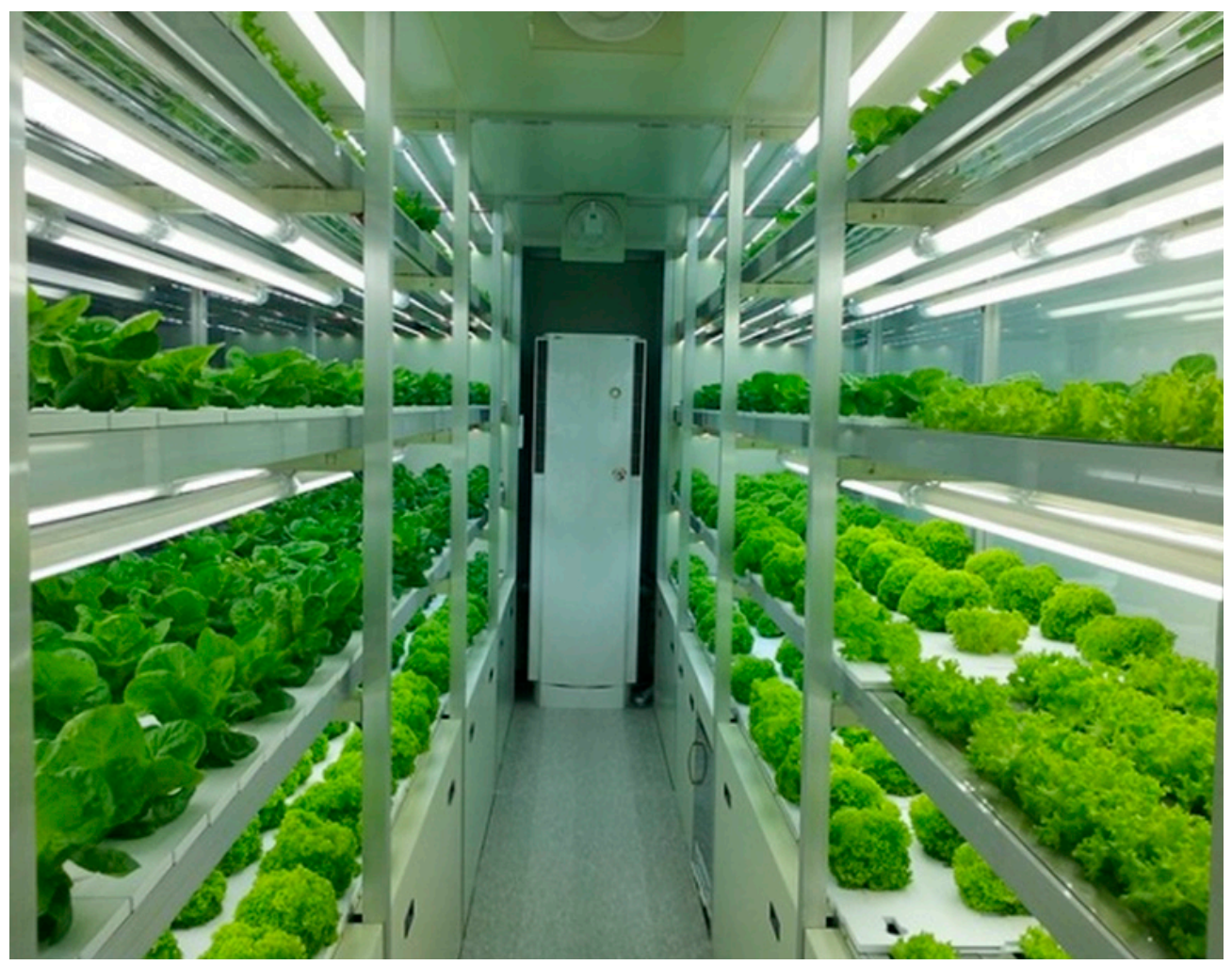

(b) 2nd generation

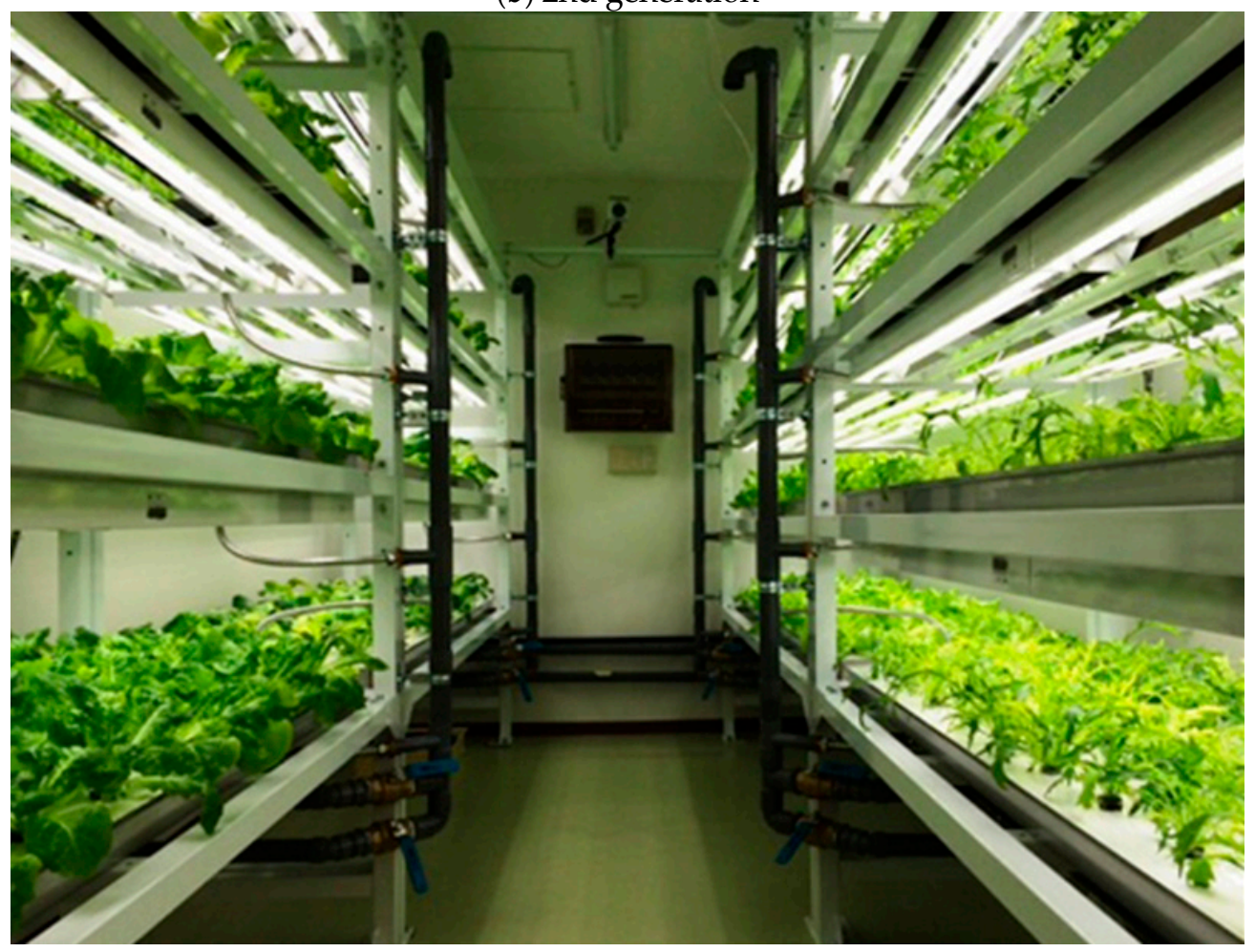

(c) 3rd generation

Figure 1. Lighting and Environmental Control with Technological Proposal for Crop Growing Factory. (a) The early plant factories that control temperature, humidity, and $\mathrm{CO}_{2}$ by adjusting lighting and ventilation (1st generation). (b) The Information and Communications Technology (ICT)-applied plant factories that create a proper lettuce growing environment by controlling indoor air quality with air purifier (2nd generation). (c) The Internet of Things (IoT)-applied plant factories that monitor the lettuce growing process in real-time through CCTV operation and indoor air quality control (the 3rd generation system being proposed in this paper). 


\subsection{Analysis of Optical Spectral Characteristics in Near-Infrared (NIR) Range Following Crop Growth Performance}

The spectral characteristics were analyzed according to the leaf surface areas, by extending the range to NIR band. Within a visible light range from $400 \mathrm{~nm}$ to $670 \mathrm{~nm}$, the light reflectance in the green area was higher than the red area, just as expected by the unique characteristics of plants that show low reflectance in the red area. Meanwhile, as shown in Figure 2, a sharp reflection was observed in an NIR range from $400 \mathrm{~nm}$ to $1200 \mathrm{~nm}$.

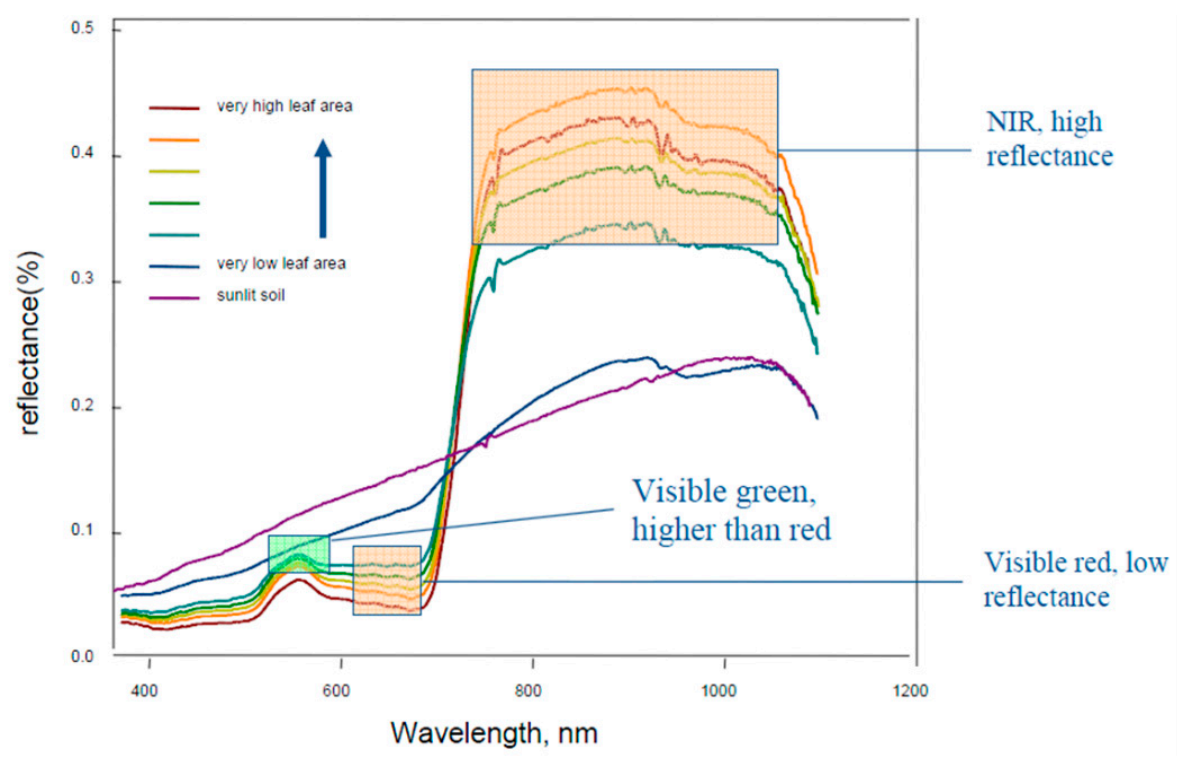

Figure 2. The light reflectance within the ranges (400 nm-1200 nm) of visible light and near infrared.

It is possible to recognize that the reflected NIR energy increases when the lamina of a healthy plant is well developed. The healthy green plants usually show high reflectance $(40-60 \%)$ and transmittance $(40-60 \%)$ in the NIR area, where a relatively low absorptance (5-10\%) can be observed. The reflectance becomes higher when $40-60 \%$ of the transmitted NIR energy has been already reflected by the sponge parenchyma, and the rest $(45-50 \%)$ is transmitted through and repeatedly reflected (multiple reflections) by the leaves beneath.

\subsection{Analysis of Crop Growth Characteristics by Images and System Design and Construction:} Imaging System Design Using Spectral Characteristics

The analysis result shows that the techniques that arithmetically use reflection properties in visible light and NIR area have a closer relationship with biomess, compared to the techniques that use visible lights or NIR separately. Thus, this imaging system was designed to conduct monitoring, according to the crop's condition, by selecting appropriate filters for individual crops and using the converged image obtained by using these filters.

An NIR filter was designed to indicate the growth condition of crops, according to their characteristics, along with a filter wheel that has four channels, on which red, green, and blue filters can be installed. The filter wheel uses a small servomotor and is operated by using a single-chip microprocessor. The images acquired through filters are processed by the NIR-Enhanced Monochrome CCD camera, which is controlled by the PC, and the motor driven by the microprocessor was designed to be synchronized with the image signals, controlled by the PC. Figure 3 shows the image acquisition system configuration using the filter wheel for monitoring, whereas Figure 4 is the flow diagram of the filter wheel operation and CCD camera control. 


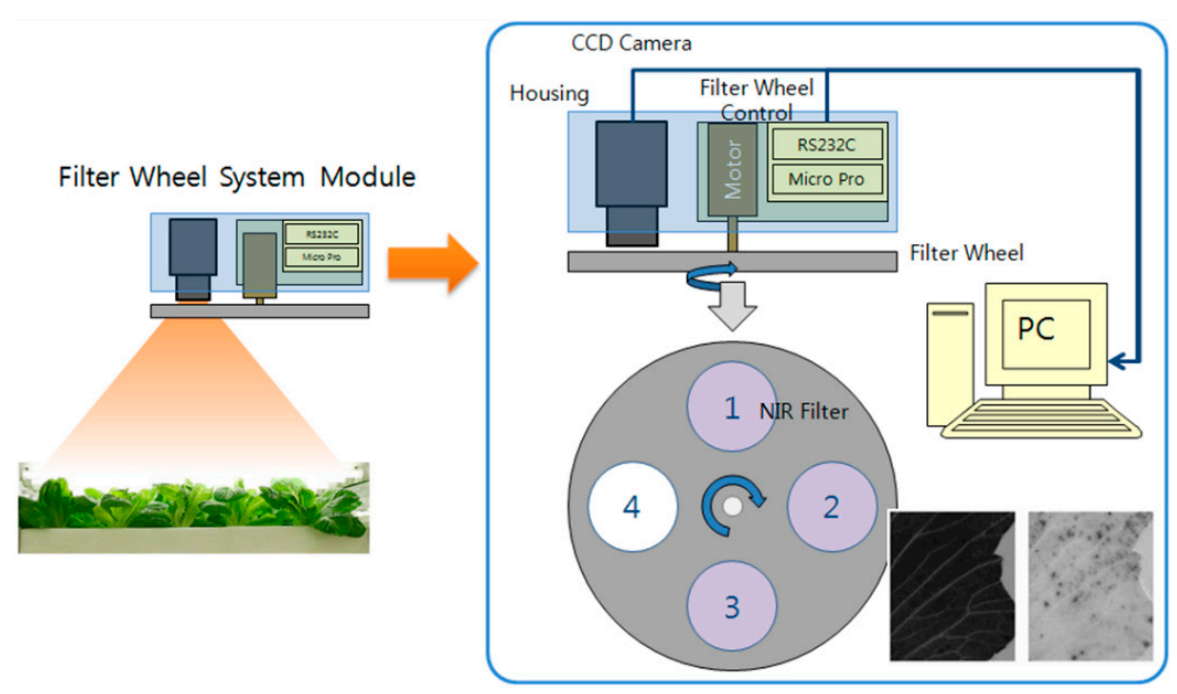

Figure 3. The image acquisition system configuration using the filter wheel for monitoring.

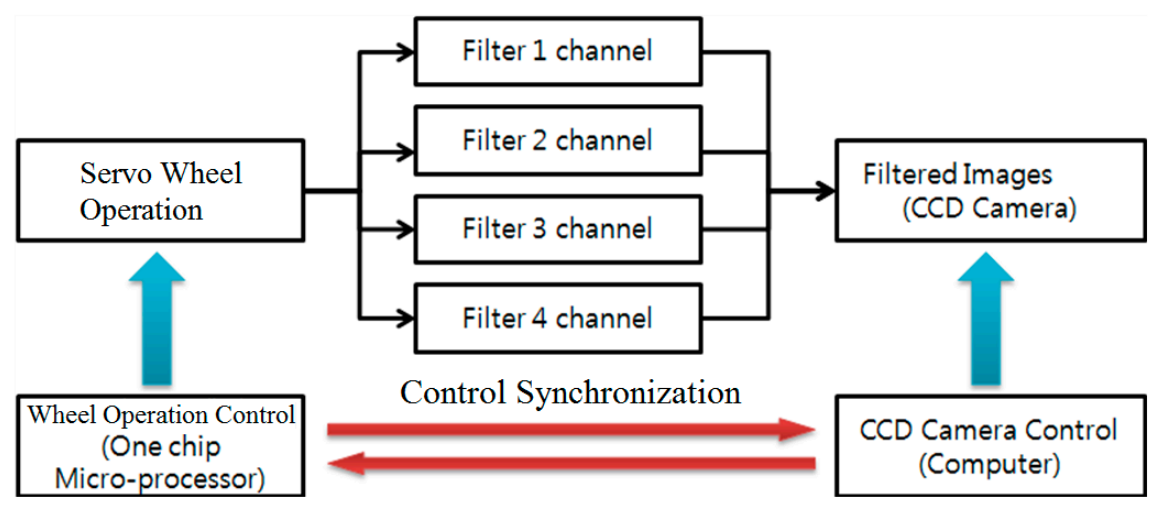

Figure 4. The flow diagram of filter wheel operation and CCD camera control.

The image acquisition range was set $\left(400 \times 400 \mathrm{~mm}^{2}\right)$ after considering the distance between the culture medium and LED and with the Equation (1). A lens with a focal length of $4.8 \mathrm{~mm}$ was selected, by applying a working distance of $400 \mathrm{~mm}$ and a field of view (crop observation range) of $400 \mathrm{~mm}$, as well as one-half of the CCD sensor size $(4.8 \mathrm{~mm})$. Figure 5 shows the camera operation range setting when selecting an appropriate lens, whereas Figure 6 shows the plant factory culture medium and the crop layout.

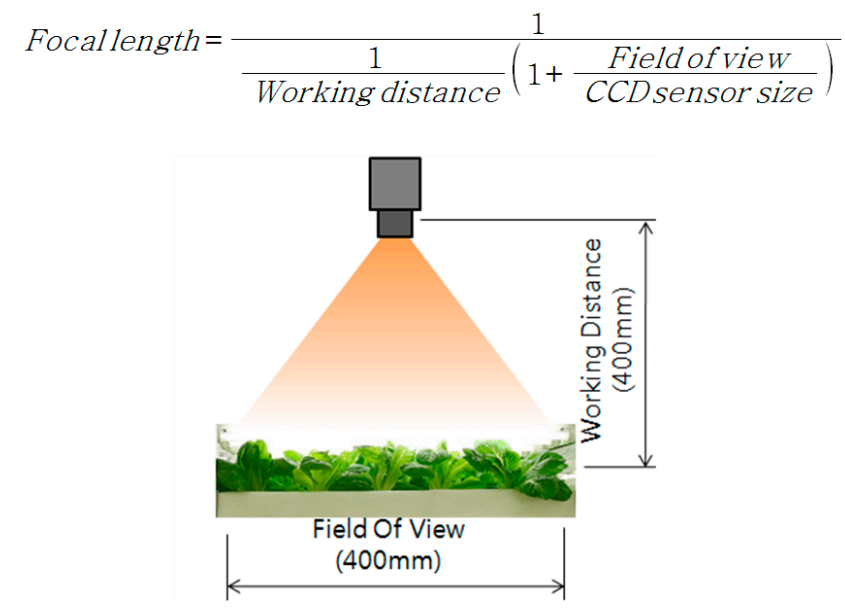

Figure 5. Setting the image acquisition range for selection of lens. 


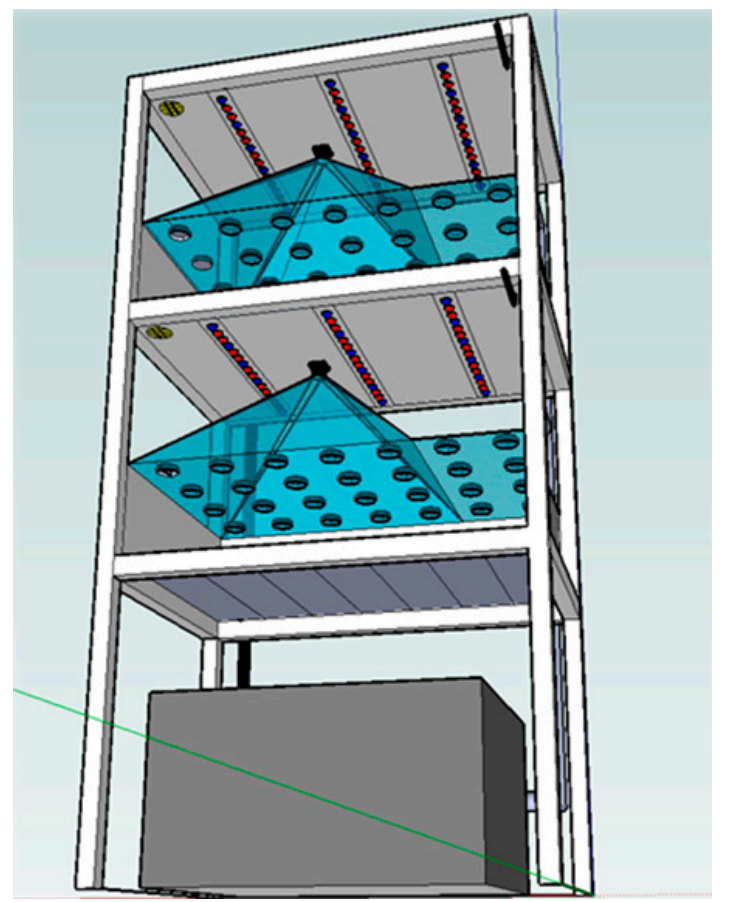

Figure 6. The experimental crop culture bed.

Figure 7 presents an actual example of an acquired image by the imaging system. Figure 8 is an example that shows both a general CCD image and one that has been applied with the NIR filter. In the latter image, it is possible to discover a tissue disorder (abnormality) caused by dehydration in upper left corner.

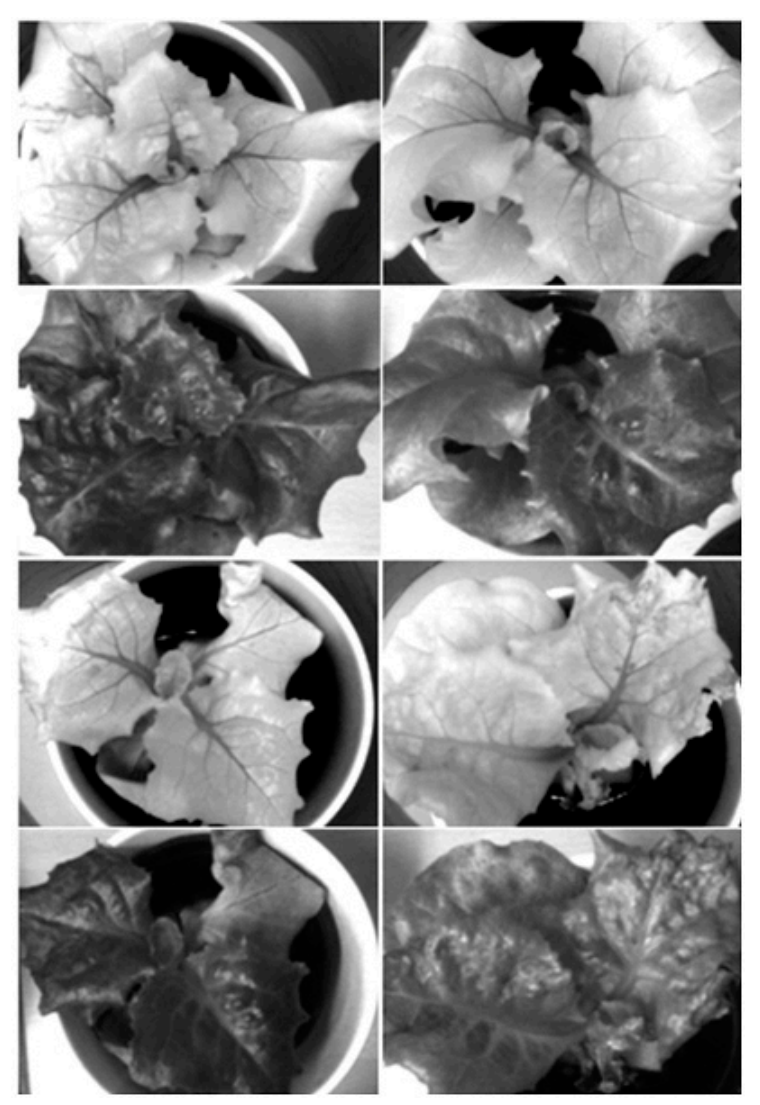

Figure 7. Actual example of image acquisition. 


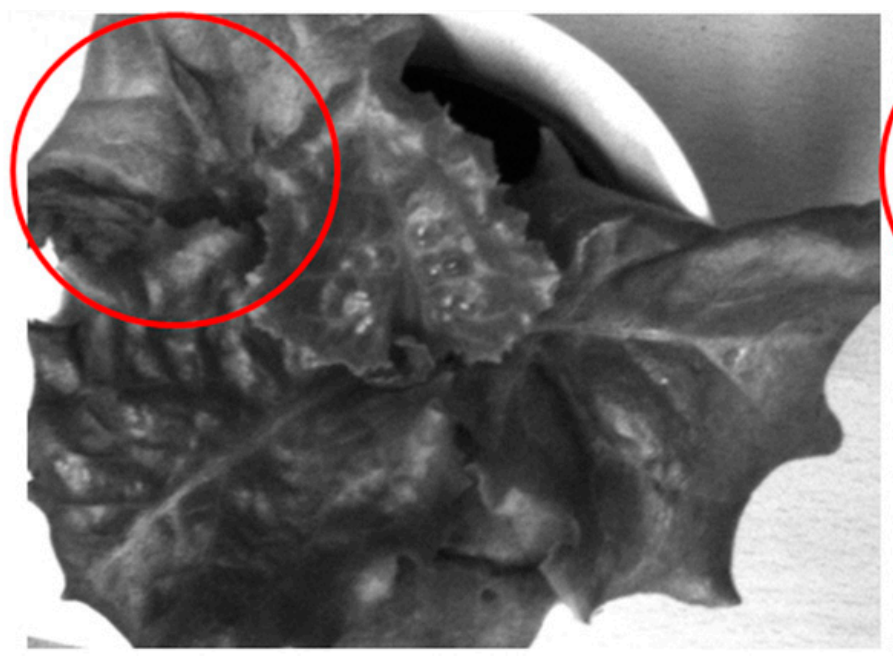

(a)

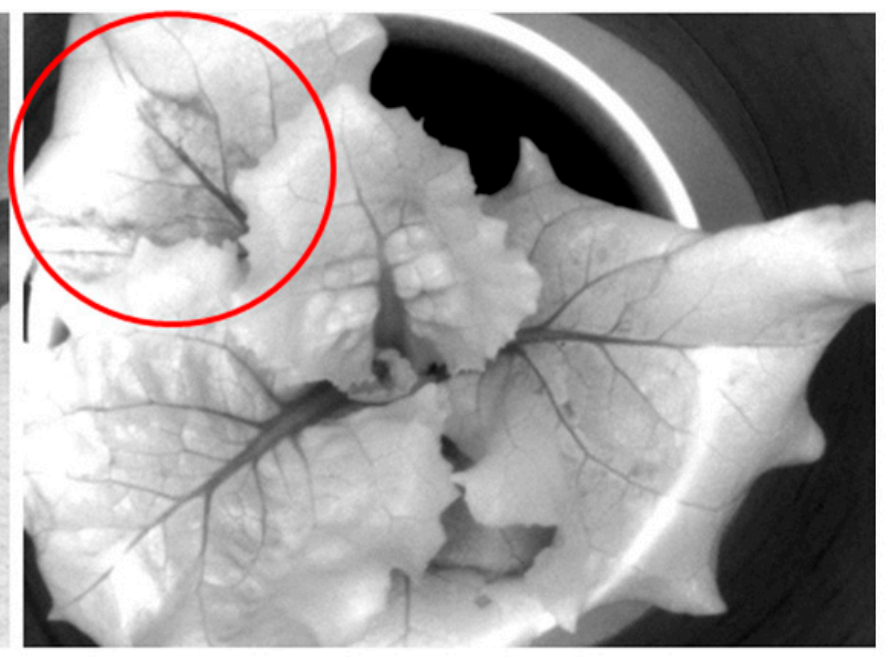

(b)

Figure 8. Comparison between general Charged-Coupled Device (CCD) image (a) and NIR filter-applied image (b).

3.3. Development of Crop Image Processing Algorithm for Determination of Required Environmental Controlled Variables

The images acquired by each filtering channel are represented, based on the digitized growth characteristics produced by the eigen filter, after subsequently being separated and converged. Figure 9 shows the outline of this process.

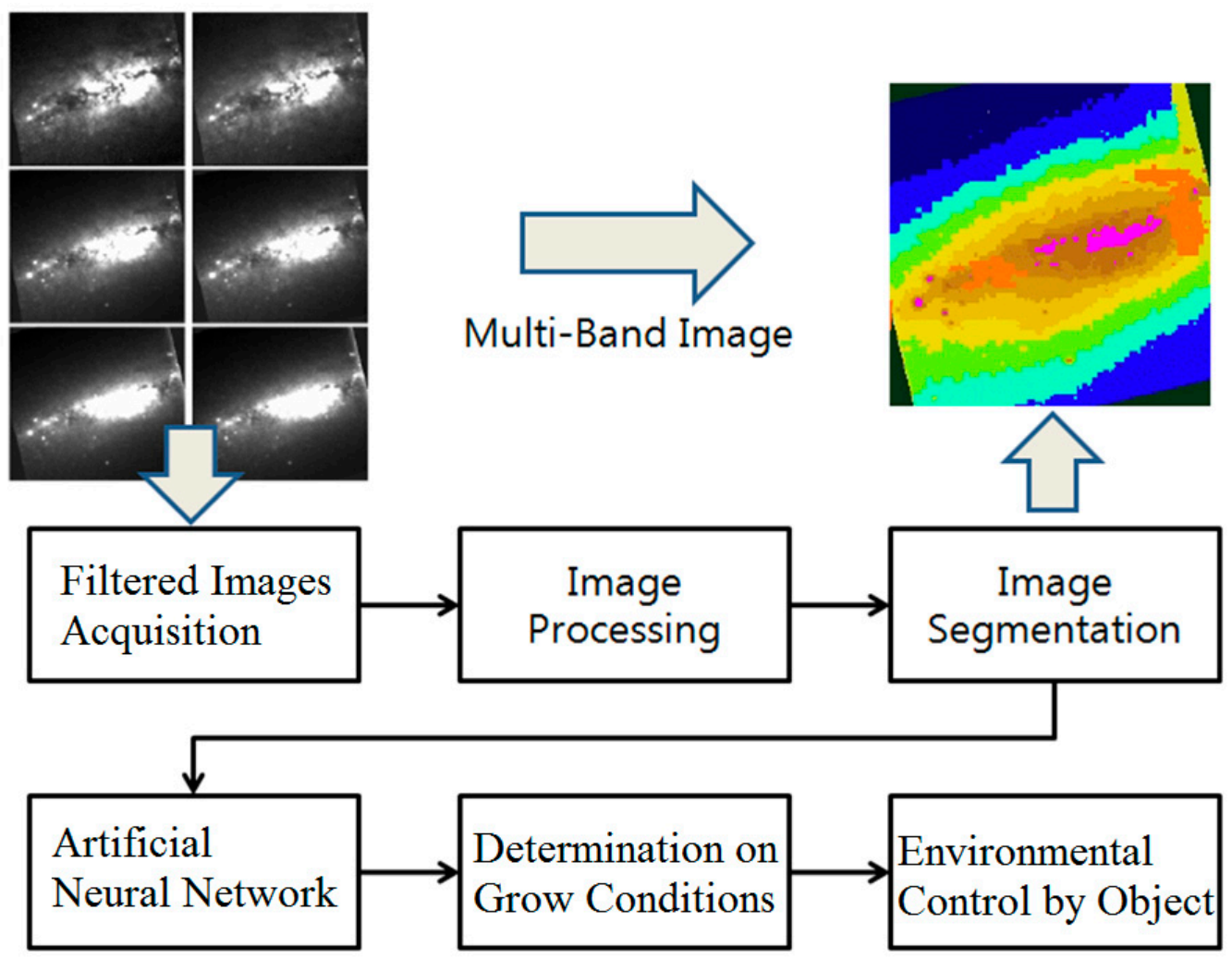

Figure 9. The image processing flow-multi-band processing.

An algorithm was designed to calculate the inherent vegetation indices for imaging within the factory, based on the spectral characteristics of the plant. The vegetation indices are the ones that are generated by the combination of several band values of satellite 
image data and have relationships with vegetation volume in the given image pixels. They are mainly used for a GIS (Geographic Information System) to determine the ecological distributions.

In this research, the images acquired by several filter channels are being used, instead of the images in individual wavelength bands transmitted from the satellite and attempt to compute suitable indices in determining each crop's condition and growth. The typical vegetation indices are the Infrared Percentage Vegetation Index (IPVI) and the Difference Vegetation Index (DVI).

3.3.1. Development of Basic Image Processing Algorithm for Determination of Crop Growth: Development of an Algorithm Detecting Abnormal Parts, Based on the NIR Images

A basic image processing algorithm was designed to determine crop growth conditions and for the processing, the image produced by the NIR filter was acquired along with a general gray-scale monochrome image. A synthetic image was created, based on the reflection characteristics of these two images to separate plant (crop) areas with the binary image for the detection. Then, the abnormal parts were detected by conducting a variety of image processing tasks. In the acquired plant area, there was a clear distinction between thallus and crown tissues, due to the NIR characteristics, so the crown range of plant leaves was distinguished through detection of the outline.

Next, image erosion, smoothing, and labeling were performed in order to remove the rest of noise, followed by sessioning in order to identify the exact branch distribution for the outline. It is possible to determine the anomalies, based on the detected unusual nodes appearing from collapse, and the crown's general branch-form distribution after completing all these processing tasks. Figure 10 shows the sequence of this image processing algorithm, whereas Figure 11 shows the distinctions between images during the process and the anomalies detected.

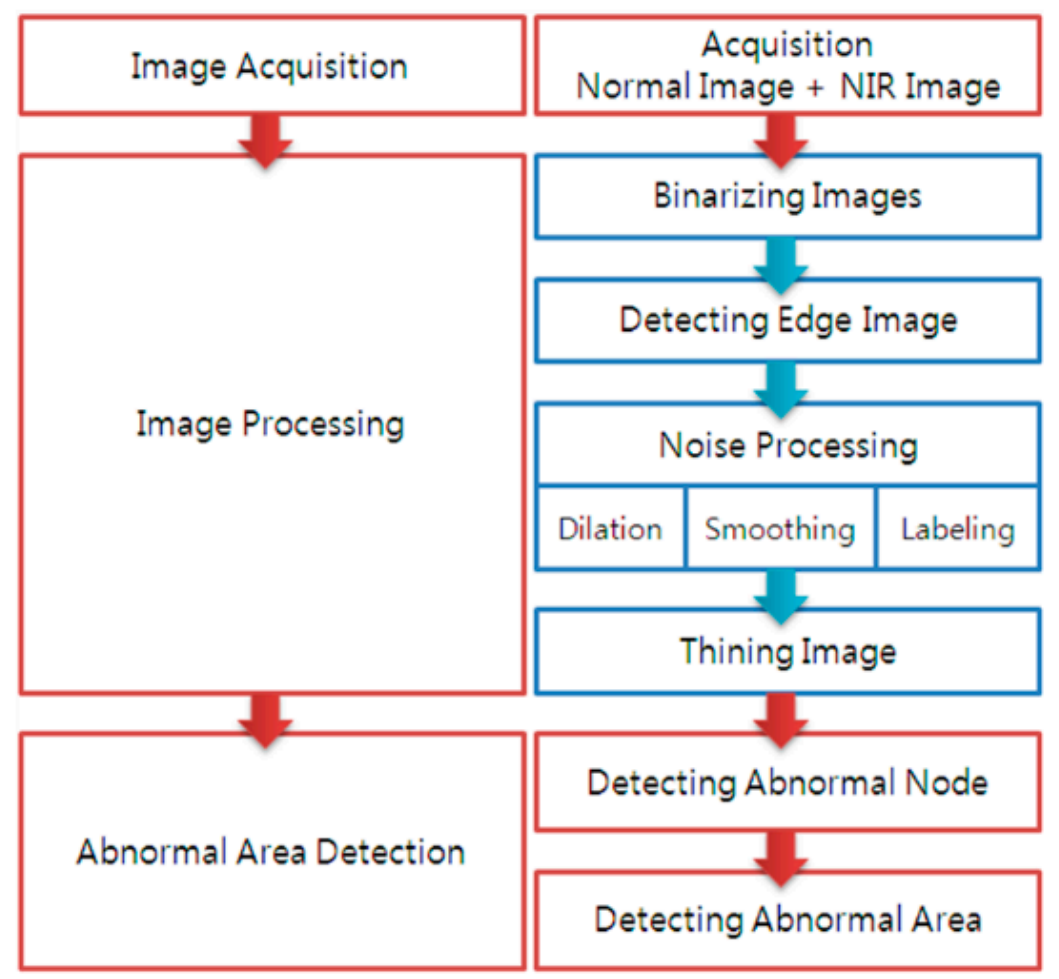

Figure 10. The anomaly-detection image processing algorithm using NIR images. 


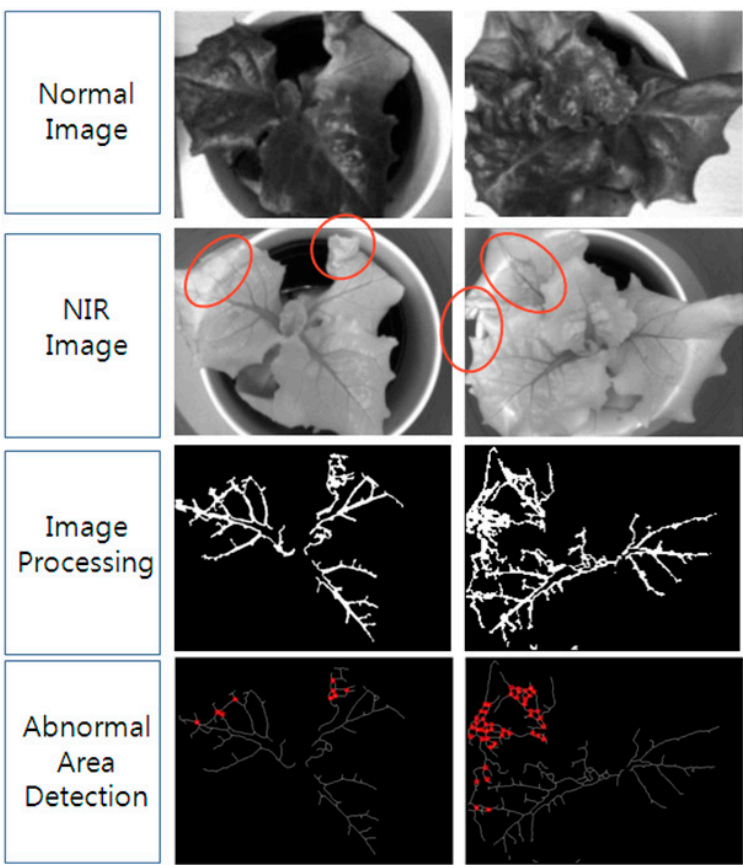

Figure 11. The image in the anomaly detection process using NIR images.

3.3.2. The Image Processing Algorithm for the Comparison of Crop Growth Conditions by Test Group

An image processing algorithm was designed to compare crop growth conditions, according to the types of LED light sources and their proportions. The vegetation region was detected by using the synthesized image that was created with the images obtained with a green filter and a blue filter. The final image was then detected with the binary image, through noise removal. Then, the images from the LED test groups were compared, by using the projected area of the vegetation region to analyze the correlation with the physical data measured after actually cultivating the crop. Figure 12 shows the images following the process sequence, along with the program used for the image processing, whereas Figure 13 shows the image processing results obtained from the arranged LED light sources.

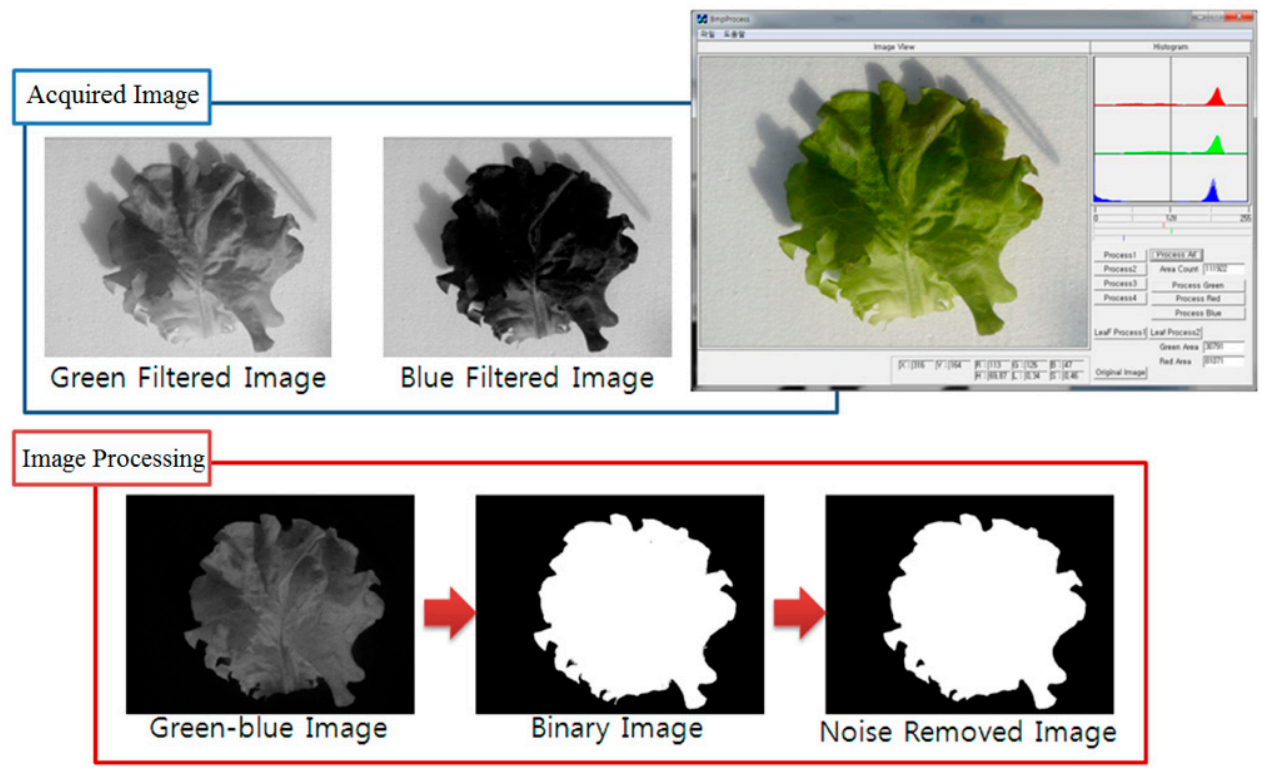

Figure 12. The image processing program and processed image. 

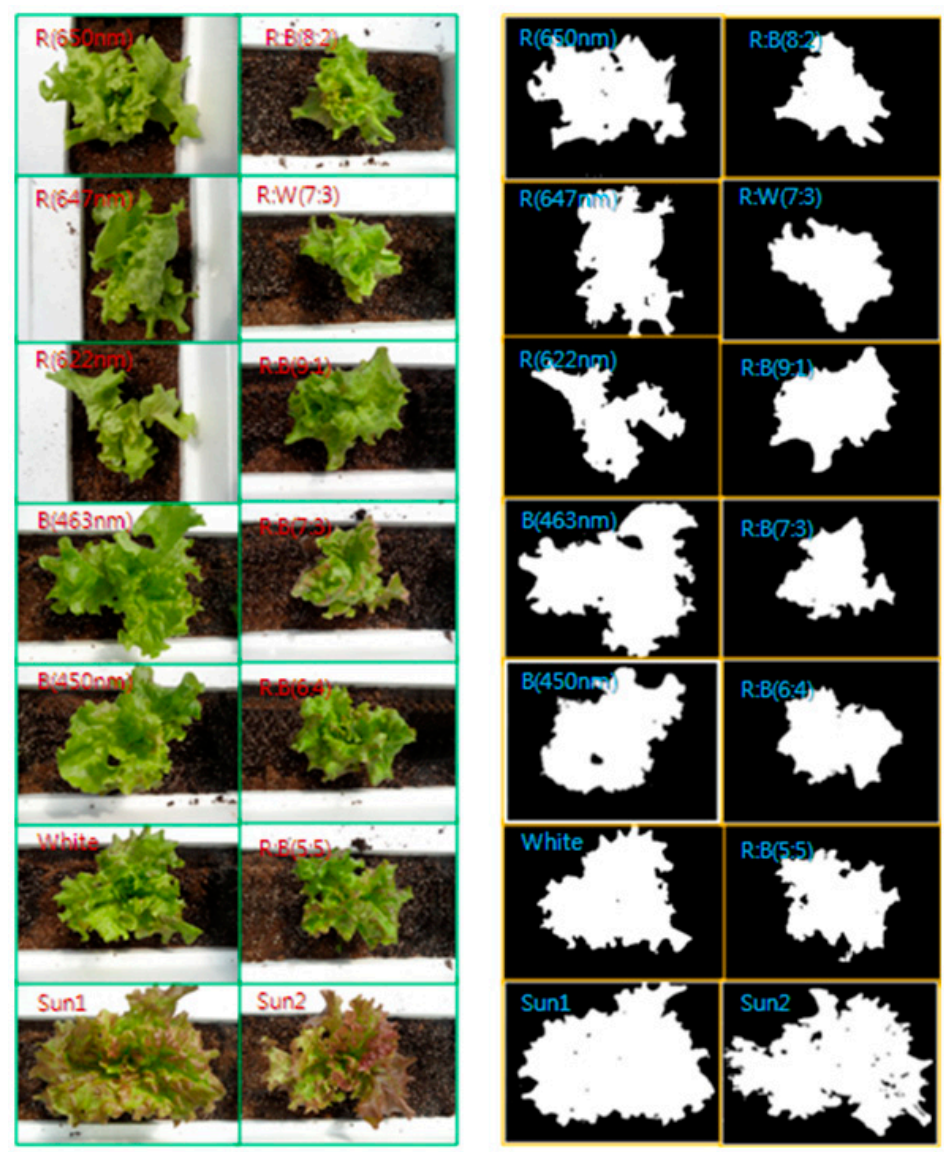

Figure 13. The crop's image and its processed image according to light sources.

Table 1 shows the physical measurement data and image data after cultivating the crop and Figure 14 shows the comparison between the image measurement data of different light source configurations.

Figure 14 shows the correlation between total projected pixels (area) after processing the image and the leaf length. For the measured crop (lettuce), the growth rate in the environment, where blue LED light source was used, was similar to the growth rate resulting from the normal environment under the sun. When compared with the actual physical data measured, it was best correlated with the leaf length.

However, this is still a basic measurement result, so the future plan is to perform a comparative analysis with the algorithm for the growth conditions from the early stages of cultivation, by constructing a multi-band filtering system that uses various types of image filters, including the NIR filter.
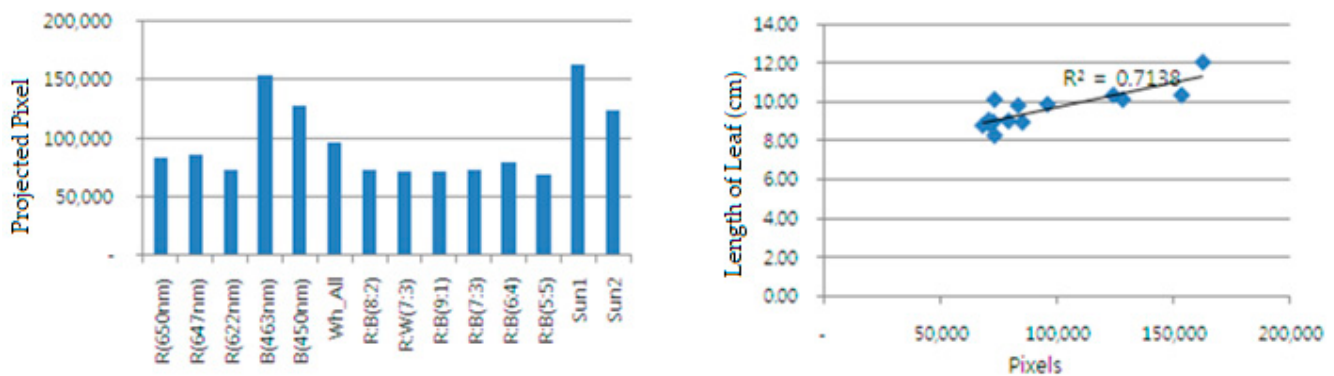

Figure 14. Comparison between growth amounts, based on image data (left), and the correlation between leaf length and image data (right). 
Table 1. Image measurements in accordance with arranged light sources and actual physical data measured.

\begin{tabular}{|c|c|c|c|c|c|c|c|c|}
\hline \multirow{2}{*}{ Test Group } & \multirow{2}{*}{$\begin{array}{c}\begin{array}{c}\text { Image } \\
\text { Measurements }\end{array} \\
\text { Projected Pixel }\end{array}$} & \multicolumn{7}{|c|}{ Actual Physical Measurements } \\
\hline & & $\begin{array}{l}\text { Number of } \\
\text { Leaves (ea) }\end{array}$ & $\begin{array}{l}\text { Leaf Fresh } \\
\text { Wight (g) }\end{array}$ & $\begin{array}{c}\text { Leaf Dry } \\
\text { Weight (g) }\end{array}$ & $\begin{array}{l}\text { Length of } \\
\text { Leaf }(\mathrm{cm})\end{array}$ & $\begin{array}{l}\text { Length of } \\
\text { Root }(\mathrm{cm})\end{array}$ & $\begin{array}{l}\text { Root Fresh } \\
\text { Weight (g) }\end{array}$ & $\begin{array}{l}\text { Root Dry } \\
\text { Weight (g) }\end{array}$ \\
\hline $\mathrm{R}(650 \mathrm{~nm})$ & 83,519 & 9.00 & 33.27 & 1.18 & 9.81 & 16.96 & 4.12 & 0.19 \\
\hline $\mathrm{R}(647 \mathrm{~nm})$ & 85,335 & 10.40 & 30.93 & 1.31 & 8.95 & 19.50 & 4.67 & 0.18 \\
\hline $\mathrm{R}(622 \mathrm{~nm})$ & 72,968 & 8.00 & 28.86 & 1.20 & 8.96 & 18.14 & 4.85 & 0.26 \\
\hline B $(463 \mathrm{~nm})$ & 153,378 & 6.20 & 25.14 & 0.20 & 10.34 & 17.44 & 4.01 & 0.20 \\
\hline $\mathrm{B}(450 \mathrm{~nm})$ & 128,208 & 7.00 & 26.30 & 1.39 & 10.12 & 17.26 & 3.32 & 0.37 \\
\hline Wh_All & 96,045 & 8.40 & 30.44 & 1.10 & 9.87 & 19.70 & 3.03 & 0.16 \\
\hline $\mathrm{R}: \mathrm{B}(8: 2)$ & 73,418 & 8.00 & 24.22 & 0.85 & 8.27 & 16.62 & 3.05 & 0.15 \\
\hline $\mathrm{R}: W(7: 3)$ & 71,340 & 8.20 & 26.48 & 1.09 & 8.85 & 18.06 & 3.25 & 0.15 \\
\hline R:B (9:1) & 70,928 & 9.40 & 30.95 & 1.41 & 9.06 & 16.18 & 3.99 & 0.19 \\
\hline $\mathrm{R}: \mathrm{B}(7: 3)$ & 73,441 & 9.40 & 32.27 & 1.12 & 10.11 & 18.62 & 3.36 & 0.14 \\
\hline $\mathrm{R}: \mathrm{B}(6: 4)$ & 79,364 & 7.80 & 25.35 & 1.18 & 9.02 & 18.86 & 3.22 & 0.16 \\
\hline R:B (5:5) & 68,379 & 8.40 & 21.63 & 1.09 & 8.79 & 18.50 & 3.23 & 0.18 \\
\hline Sun 1 & 162,485 & 7.40 & 42.63 & 1.87 & 12.03 & 16.36 & 2.99 & 0.13 \\
\hline Sun 2 & 124,183 & 8.60 & 39.53 & 2.11 & 10.34 & 19.50 & 3.62 & 0.22 \\
\hline
\end{tabular}

\subsection{The Crop Cultivation Test Groups for Environmental Control and Monitoring: Crop Cultivation System}

An aeroponic crop cultivation system was constructed by preparing a single closed building $\left(10 \mathrm{~m}^{2}\right)$ to apply the environmental control and monitoring systems. The cultivation standard size was $900 \mathrm{~mm} \times 600 \mathrm{~mm} \times 1700 \mathrm{~mm}$, and eight test groups, with a 2-story bed each, were prepared. The system also allowed the red and blue LED light sources to be combined. Then, the nutrient solution tank and pump were installed at the lower part, along with wireless control device and sensor transmission unit for convenient external control. Figure 15 shows the constructed design of the crop cultivation system, whereas Figure 16 shows the light combinations of the individual test groups for the crop cultivation experiment.
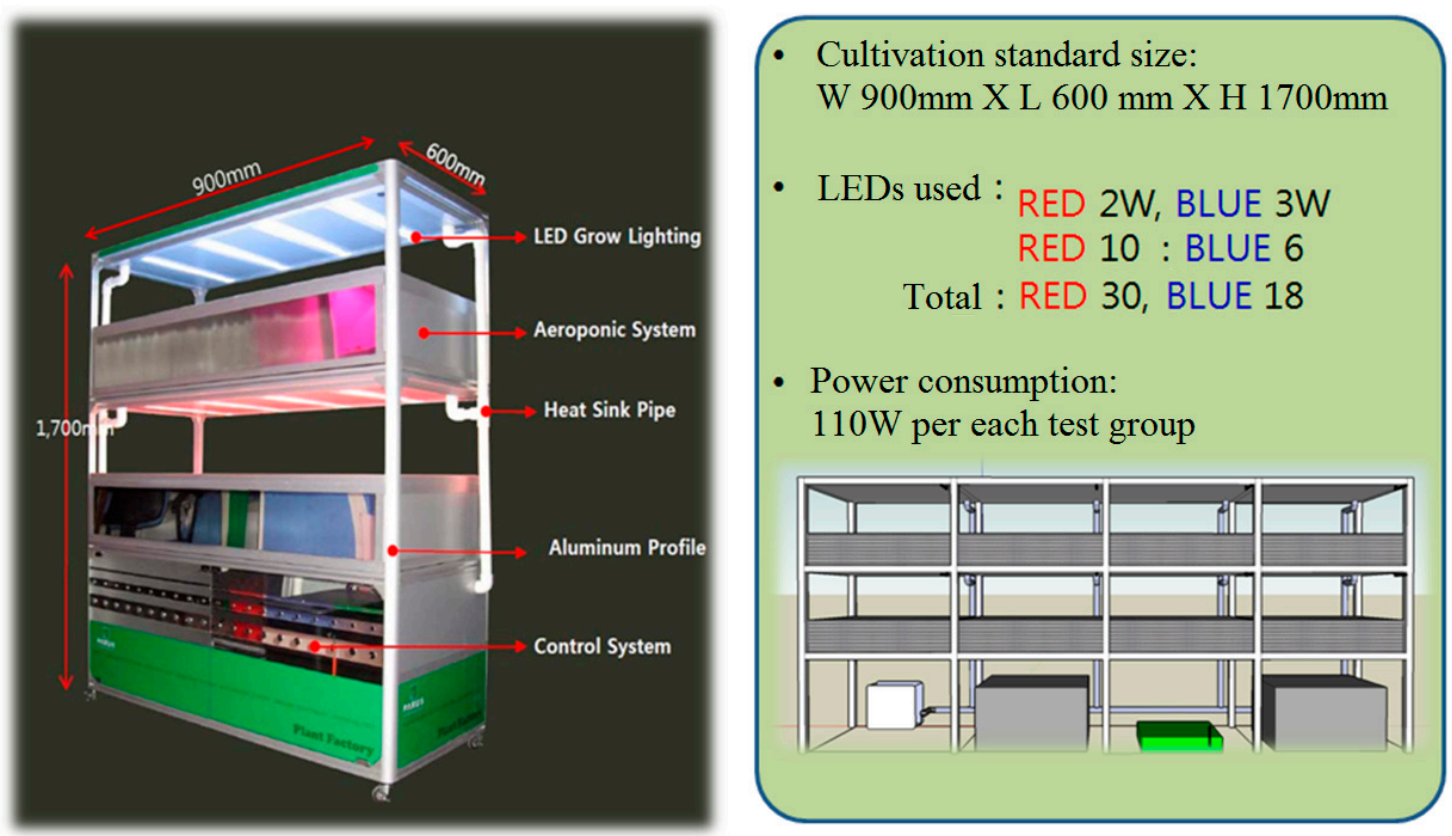

Figure 15. The design of cultivation test group for environmental control and monitoring. 


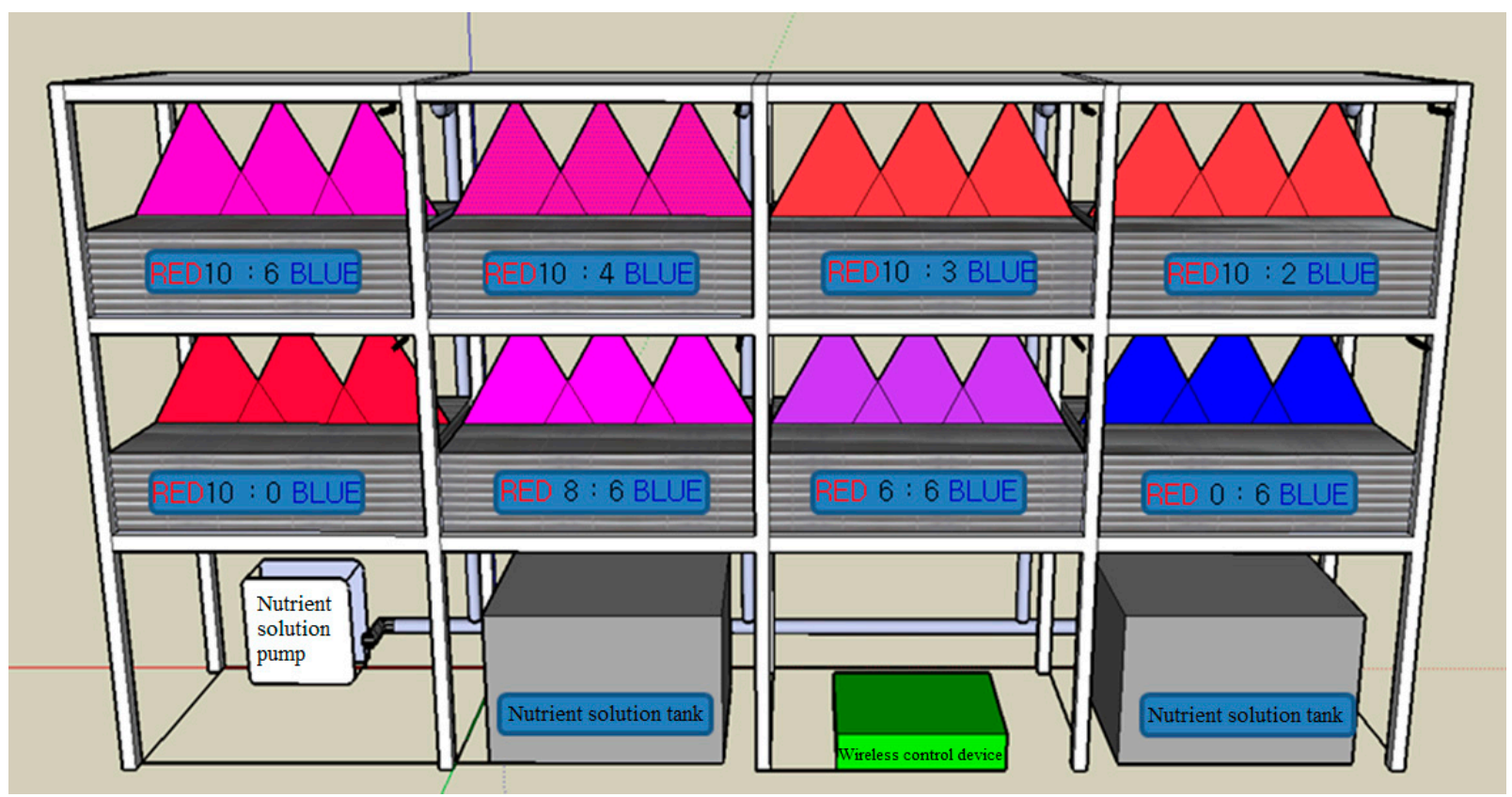

Figure 16. The light combinations of individual test groups for the crop cultivation experiment.

\section{Experiment}

\subsection{Experiment Subjects}

The experiments were conducted in three phases using the hydroponics technique. The dimension of the employed plant factory was $4420 \mathrm{~mm} \times 3060 \mathrm{~mm} \times 2170 \mathrm{~mm}$.

The lettuce (Lactuca sativa L.) variety adopted for the experiment was "Seonmangjeokchukmyeon" (Nongwoo, Korea); it is one of the loose-leaf (var. crispa) variants among the leafy vegetable commodities.

\subsection{Experimental Design}

The duration for lettuce cultivation is normally 28 days from the time of sowing, as per the hydroponics standard in the factory. The medium introduced for hydroponics was a polyurethane sponge. The nutrient solution was supplied through the lowermost beds with storage bottom watering. The number of lettuce plants in 1 bed was 28 stocks, and the seedling planting was done in the shape of a pentagon. A dedicated closed central ventilation system was employed for ventilation inside the factory. The LED (Light Emitting Diode) used for the illumination of the experimental plot was $1 \mathrm{~W}$ in 15 levels, with a power consumption of $18 \mathrm{~W}$ PCB (Printed Circuit Board), and a loss of 5\%, and of $15 \%$ from power supplier circuit. Multi-layer beds were implemented to make the wavelength of illumination source different for lettuce. The amount of light maintained for the color of light source per bed as PPDF (Photosynthetic Photon Flux Density) was $200 \mu \mathrm{mol} \cdot \mathrm{m}^{-2} \cdot \mathrm{s}^{-1}$ under the condition that all light sources inside of the factory were $\mathrm{ON}$.

\subsection{Measurement and Analysis}

The number of particulate pollutants and airborne microorganisms inside the plant factory was measured thrice (on the first day of the experiment, the middle of the experiment, and the last day of the experiment), per experimental plot, and the average value was adopted as the representative value. To set the baseline concentration of particulate pollutants and airborne microorganisms, their concentrations outdoors were also monitored. The growth indicators of 10 attributes for the final growth and development of lettuce were estimated during the 28 days of the formal planting of lettuce in the main bed.

To monitor particulate pollutants inside the plant factory, TSP (Total Suspended Particulate matter), PM (Particulate Matter) 10, PM2.5, and PM1 were measured, using 
light scattering-type direct-reading indicators (Dustmate, DM 11431, Turnkey Instruments Ltd., Northwich, UK). For the measurement of airborne microorganisms, a 1-stage cascade impactor (BUCK Bio culture B30120, A.P. Buck Inc., Orlando, FL, USA) was utilized.

Among airborne microorganisms, airborne bacteria and airborne fungi were selected as experiment subjects and sampled using Trypticase Soy Agar media (TSA, Lot 2087730, Becton Dickinson and Company, Franklin Lakes, NJ, USA), wherein 500 mg of cycloheximide was added to suppress the growth of airborne bacteria, and SDAC (Sabouraud Dextrose Agar + Chloramphenicol) agar media, wherein $100 \mathrm{mg}$ of hemichloride was added to suppress fungal growth. The sampled medium was immediately sealed with parafilm after sampling to avoid contamination, and culturing was carried out in the microorganism analysis laboratory.

The culture was maintained at $37^{\circ} \mathrm{C}$ for $1-2$ days for airborne bacteria, and at $20^{\circ} \mathrm{C}$ for 3-5 days for airborne fungi. After the completion of culturing, the concentration of airborne bacteria and airborne fungi was calculated as in Equations (1) and (2), by dividing the counting of colonies in the culture media by the volume of sampled air $\left(\mathrm{m}^{3}\right)$ :

$$
\begin{gathered}
\frac{\text { CFU (Colony Forming Unit) }}{\mathrm{m}^{3}}=\frac{\text { Colony counted on agar plate }}{\text { Air volume }\left(\mathrm{m}^{3}\right)} \\
\text { Air volume }\left(\mathrm{m}^{3}\right)=\frac{20 \mathrm{~L}}{\min } \times \frac{\text { Sampling time }(\mathrm{min})}{10^{3}}
\end{gathered}
$$

The temperature and relative humidity of the plant factory during the experiment period were measured as a logarithm of measured value at a $1-h$ interval, by installing a dry-bulb thermometer and a wet-bulb thermometer in the facility.

\subsection{Data Analysis}

For the statistical analysis of measured data, IBM SPSS (Statistical Package for the Social Sciences) Statistics were used to determine statistical reliability and significance, according to the light source variables for lettuce, during the experiment. Since the variation is large in the growth patterns of crops in this experiment, these patterns were categorized as artificially induced phenomena, rather than natural ones. A Kruskal-Wallis test was carried out as part of the non-parametric verification tests under the assumption that the data follows non-normal distribution. A run test was conducted to find out if there were any growth patterns specific to the subjected crop, by setting up control 2 to compare lettuce growth from other factories. The reliability of data, as per the categorization of all light sources, was assessed, and statistical data, using a Bootstrap sample of 1000, was proposed to secure reliability.

\section{Results and Discussion}

\subsection{First Experiment}

Table 2 shows the environmental variables inside the plant factory and the consequent growth status of the lettuce. The experiment proceeded without equipping the plant factory with ventilation and air conditioning.

The temperature and relative humidity were maintained at $111.2 \pm 1.3{ }^{\circ} \mathrm{C}$ and $31.3 \pm 2.2 \%$, respectively, as natural environmental conditions in 1-h intervals. Nonetheless, all the planted lettuce died after 14 days of planting. This might have been caused by the low temperature and low humidity conditions that are not favorable for growing lettuce, as well as the large amounts of contaminants in the air, since many machines were stacked inside newly built factories, and dust, accumulated on the lettuce leaves, could be observed. Research on air pollutants will be needed via experiments in similar environments in the future.

The amount of particulate pollutants TSP, PM10, PM2.5, and PM1 inside the plant factory was impossible to measure since it exceeded the measurable level of the testing machine. On the other hand, the TSP value outside the plant factory was measured as 
$91.64 \pm 44.47 \mu \mathrm{g} / \mathrm{m}^{3}$, with $32.60 \pm 15.56 \mu \mathrm{g} / \mathrm{m}^{3}$ of PM10. The PM2.5 level was found to be $16.45 \pm 1.26 \mu \mathrm{g} / \mathrm{m}^{3}$, whereas PM1 was $7.10 \pm 0.32 \mu \mathrm{g} / \mathrm{m}^{3}$. The air pollutants inside the plant factory might be due to the unclean condition and absence of ventilation, rather than being caused by an external source.

Table 2. Environmental variable in the plant factory.

\begin{tabular}{|c|c|c|c|c|c|c|}
\hline \multicolumn{7}{|c|}{ First-Phase Experiment (1-28 February) } \\
\hline \multirow{3}{*}{$\begin{array}{c}\text { Pollutant } \\
\text { Airborne fungi } \\
\text { Airborne bacteria }\end{array}$} & \multirow[t]{3}{*}{ Spot } & & \multirow[t]{2}{*}{ Spot } & \\
\hline & & \multicolumn{2}{|c|}{$427 \pm 228 \mathrm{CFU} / \mathrm{m}^{3}$} & & \multicolumn{2}{|c|}{$540 \pm 210 \mathrm{CFU} / \mathrm{m}^{3}$} \\
\hline & & \multicolumn{2}{|c|}{$540 \pm 210 \mathrm{CFU} / \mathrm{m}^{3}$} & \multirow{5}{*}{ Out } & \multicolumn{2}{|c|}{$476 \pm 170 \mathrm{CFU} / \mathrm{m}^{3}$} \\
\hline \multirow{4}{*}{ Particulate matter } & & TSP & $>6579 \mu \mathrm{g} / \mathrm{m}^{3}$ & & TSP & $91.64 \pm 44.47 \mu \mathrm{g} / \mathrm{m}^{3}$ \\
\hline & In & PM10 & $>6579 \mu \mathrm{g} / \mathrm{m}^{3}$ & & PM10 & $32.6 \pm 15.56 \mu \mathrm{g} / \mathrm{m}^{3}$ \\
\hline & & PM2.5 & $>657.9 \mu \mathrm{g} / \mathrm{m}^{3}$ & & PM2.5 & $16.45 \pm 1.26 \mu \mathrm{g} / \mathrm{m}^{3}$ \\
\hline & & PM1 & $>657.9 \mu \mathrm{g} / \mathrm{m}^{3}$ & & PM1 & $7.10 \pm 0.32 \mu \mathrm{g} / \mathrm{m}^{3}$ \\
\hline
\end{tabular}

Micro-climate conditions (temperature: $11.2 \pm 1.3^{\circ} \mathrm{C}$, relative humidity: $31.3 \pm 2.2 \%$ ) in the plant factory

Result: All experimental plants died after of 14 days of planting. (It might be due to the low temperature and humidity conditions and the high dust level.)

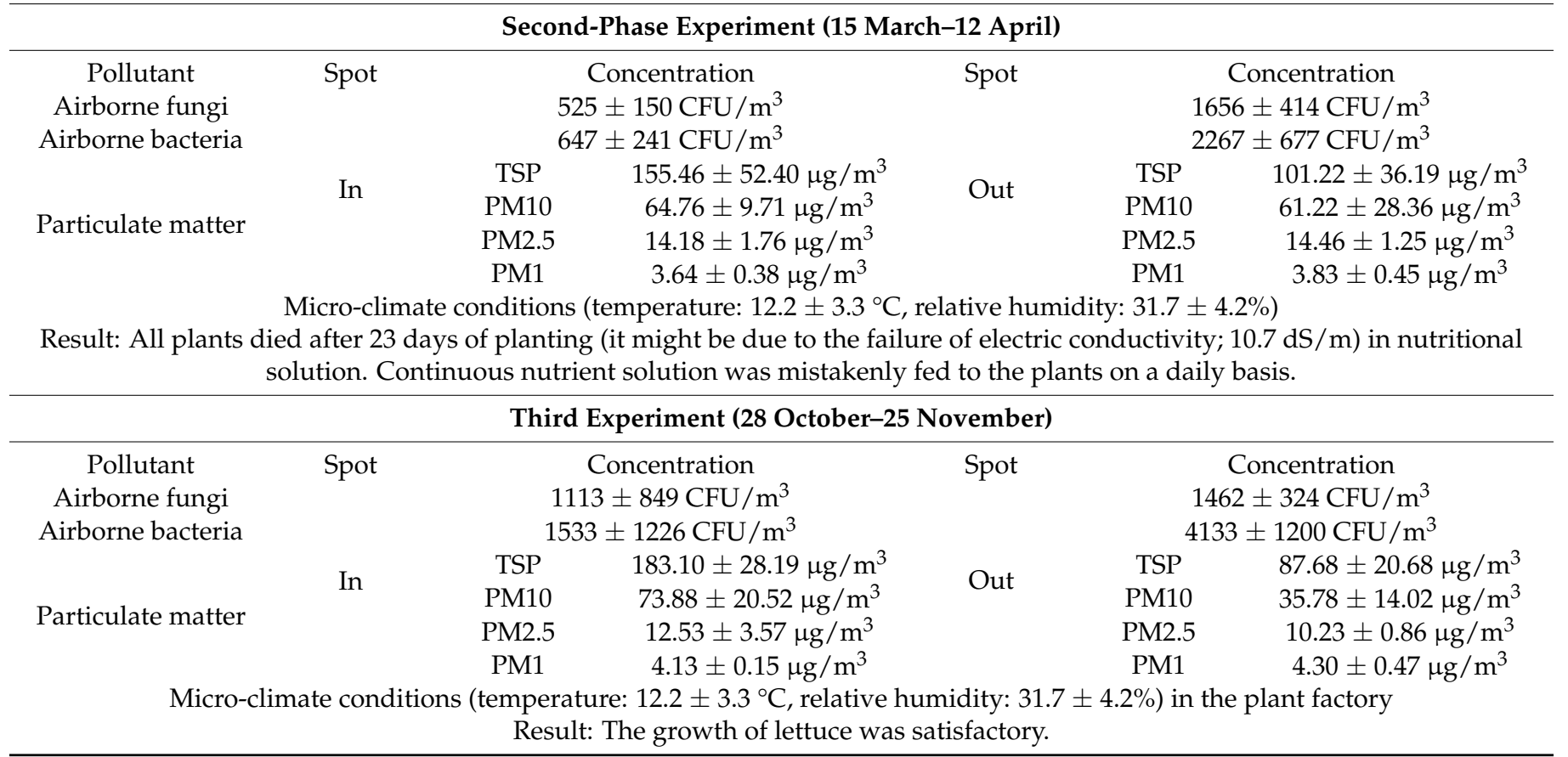

The concentrations of airborne bacteria and fungi were found to be $427 \pm 228 \mathrm{CFU} / \mathrm{m}^{3}$ and $540 \pm 210 \mathrm{CFU} / \mathrm{m}^{3}$, respectively, in the factory, and $540 \pm 210 \mathrm{CFU} / \mathrm{m}^{3}$ and $476 \pm 170 \mathrm{CFU} / \mathrm{m}^{3}$, respectively, outside the factory. With almost no difference in airborne microbial concentration inside and outside the plant factory, it was impossible to judge that these microorganisms were moving through air flow in and out of the plant factory.

\subsection{Second Experiment}

During the second experiment, ventilation inside the plant factory was sufficiently carried out to correct the failure during the first experiment, the temperature was maintained at $12.2 \pm 3.3^{\circ} \mathrm{C}$ at 1 -h intervals, and the humidity level was $31.7 \pm 4.2 \%$, as naturally adjusted. Nonetheless, all the lettuce died after 20 days of planting, without leaving a particular proof of cause. Since tipburn was observed from the lettuce, and the leaves were dried, efforts were made on the plant to revive it, but this could not stop the death of the lettuce that occurred 20 days after planting, or 8 days before harvest. It would be appropriate to say that lettuce could not tolerate the temperature and humidity conditions that are not favorable for its original growth; since this crop showed good performance 
under the same environmental conditions, however, the critical cause of tipburn could not be found. The cause of tipburn is understood to be the high temperature and potassium deficiency [19]. Still, all deaths of lettuce by tipburn might not be caused by potassium deficiency or physiological problems within the lettuce itself but might be due to a contagious disease inside the plant factory or some difference in nutrient solution. The detailed and correct cause of death could not be established.

The concentration of particulate pollutants inside the plant factory was measured as $155.46 \pm 52.40 \mu \mathrm{g} / \mathrm{m}^{3}$ of TSP, $64.76 \pm 9.71 \mu \mathrm{g} / \mathrm{m}^{3}$ of PM10, $14.18 \pm 1.76 \mu \mathrm{g} / \mathrm{m}^{3}$ of PM2.5, and $3.64 \pm 0.38 \mu \mathrm{g} / \mathrm{m}^{3}$ of PM1; outside the plant factory, however, TSP value was $101.22 \pm 36.19 \mu \mathrm{g} / \mathrm{m}^{3}$, PM10 was $61.22 \pm 28.36 \mu \mathrm{g} / \mathrm{m}^{3}$, PM2.5 was $14.46 \pm 1.25 \mu \mathrm{g} / \mathrm{m}^{3}$, and PM1 was $3.83 \pm 0.45 \mu \mathrm{g} / \mathrm{m}^{3}$. The concentration inside the plant factory could be higher than that of outside, but the levels were not that high, compared to the level of fine particles during the first experiment.

The concentration of airborne microorganisms was found to be $647 \pm 241 \mathrm{CFU} / \mathrm{m}^{3}$ for bacteria and $525 \pm 150 \mathrm{CFU} / \mathrm{m}^{3}$ for airborne fungi inside the plant factory, and $2267 \pm 677 \mathrm{CFU} / \mathrm{m}^{3}$ and $1656 \pm 414 \mathrm{CFU} / \mathrm{m}^{3}$, respectively, outside the plant factory. This shows a rather higher concentration in airborne microorganisms than inside. The concentration of airborne microorganisms was also observed to have considerably increased outside the plant factory but increased only a little bit inside the plant factory, compared to the first experiment. The increase in the concentration of airborne microorganisms may be attributable to the yellow sand phenomena that occurred twice (on 19-22 March), causing increases in microorganism concentration under the outside environment [20-22]. The increases in airborne microorganism concentration occurred together inside and outside the plant factory.

In addition, higher airborne microorganism concentration was confirmed to have been observed from past meteorological data in spring, especially in the month of July.

\subsection{Third Experiment}

A ventilation facility was provided to the factory as a supplementary measure for the failures during the first and the second experiments, the capacity and operating environment of ventilation were arranged as per the design specification in ISO 14644-9 in the form of a clean room; thus, the maintained temperature was $20.0 \pm 1.1^{\circ} \mathrm{C}$ at 1 -h intervals, and the relative humidity was adjusted to $55.0 \pm 4.3 \%$, by artificial means. The lettuce could be harvested after 28 days of planting.

The concentration of particulate pollutants inside the factory was as follows: TSP of $87.68 \pm 20.68 \mu \mathrm{g} / \mathrm{m}^{3}$, PM10 of $35.78 \pm 14.03 \mu \mathrm{g} / \mathrm{m}^{3}, \mathrm{PM} 2.5$ of $10.23 \pm 0.86 \mu \mathrm{g} / \mathrm{m}^{3}$, and PM1 of $4.30 \pm 0.47 \mu \mathrm{g} / \mathrm{m}^{3}$. On the other hand, the TSP value from outside of the factory was found to be $183.10 \pm 28.19 \mu \mathrm{g} / \mathrm{m}^{3}$, with $73.88 \pm 20.52 \mu \mathrm{g} / \mathrm{m}^{3}$ of PM10, $12.53 \pm 3.57 \mu \mathrm{g} / \mathrm{m}^{3}$ of PM2.5, and $4.13 \pm 0.15 \mu \mathrm{g} / \mathrm{m}^{3}$ of PM1. By looking at the data of microorganisms and particulate pollutants from inside, as well as outside the factory, a pure environment could be confirmed to have been maintained inside the plant factory.

The concentration of airborne microorganisms inside the factory was found to be $1533 \pm 1226 \mathrm{CFU} / \mathrm{m}^{3}$ of bacteria and $1133 \pm 849 \mathrm{CFU} / \mathrm{m}^{3}$ of fungi, whereas the concentration of airborne microorganisms outside the factory was $4133 \pm 1200 \mathrm{CFU} / \mathrm{m}^{3}$ of bacteria and $1462 \pm 324 \mathrm{CFU} / \mathrm{m}^{3}$ of fungi. From the data, the concentration of airborne microorganisms was clearly higher outside the factory, than inside. A much higher concentration of airborne microorganism was observed, compared to the results from the first and second experiments. This may be due to temperature increases during experiments, which raised microbial counts [23-25]. Those microorganisms, which are beneficial for lettuce growth, were also assumed to have grown. The growth of microorganisms in the soil could significantly affect the growth of lettuce, since plants would not be affected much inside of a plant factory; however, it could be a hindrance in the growth and development of crops. 


\subsection{Statistical Data Analysis}

The growth pattern of lettuce in the plant factory could be clearly deduced from the various indices shown in Figure 17.

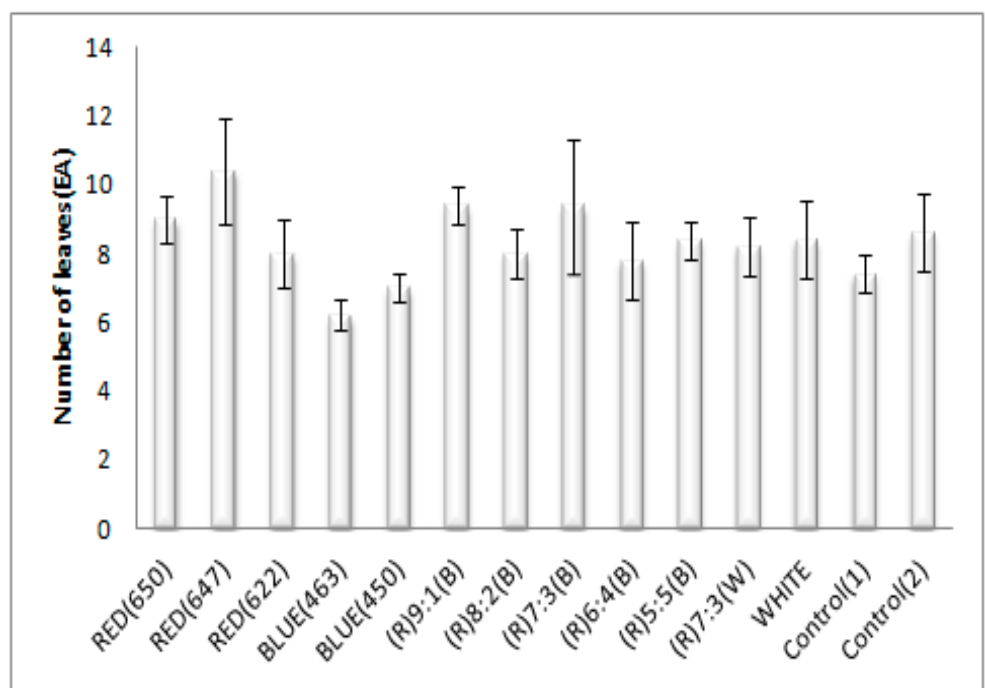

(a) Number of leaves

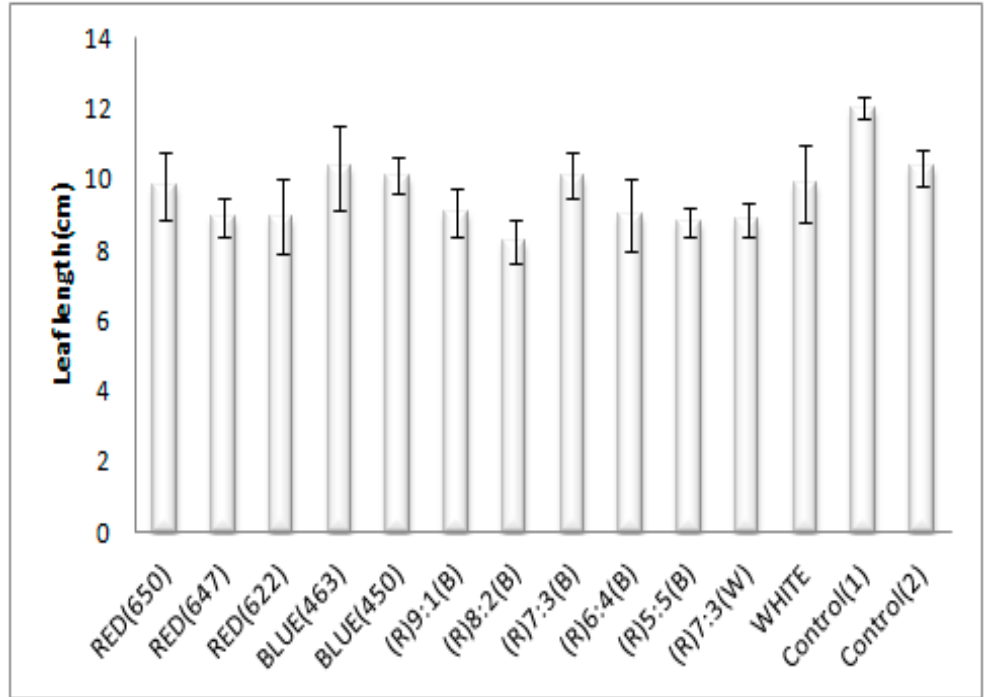

(b) Leaf length

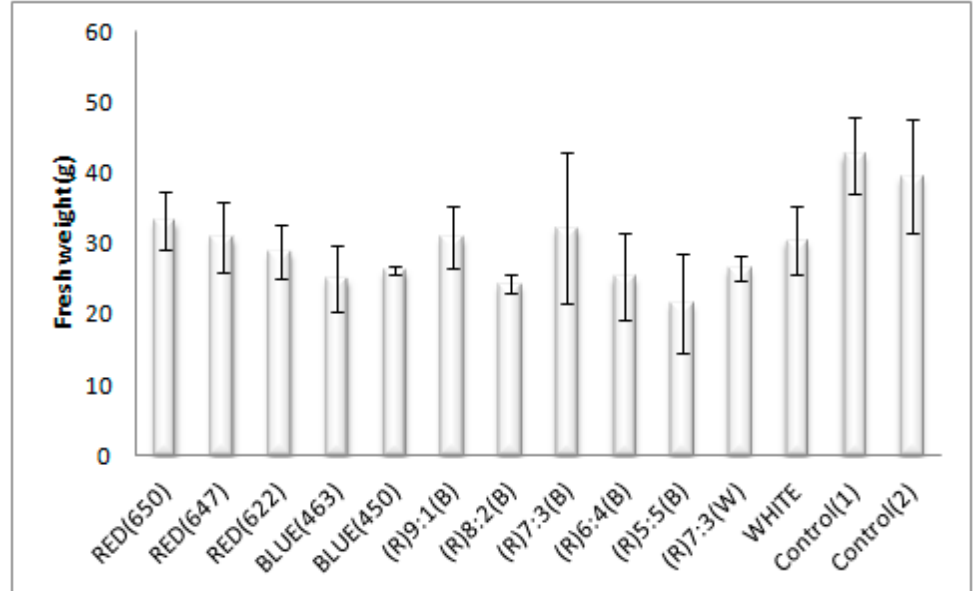

(c) Fresh weight of leaf

Figure 17. Cont. 


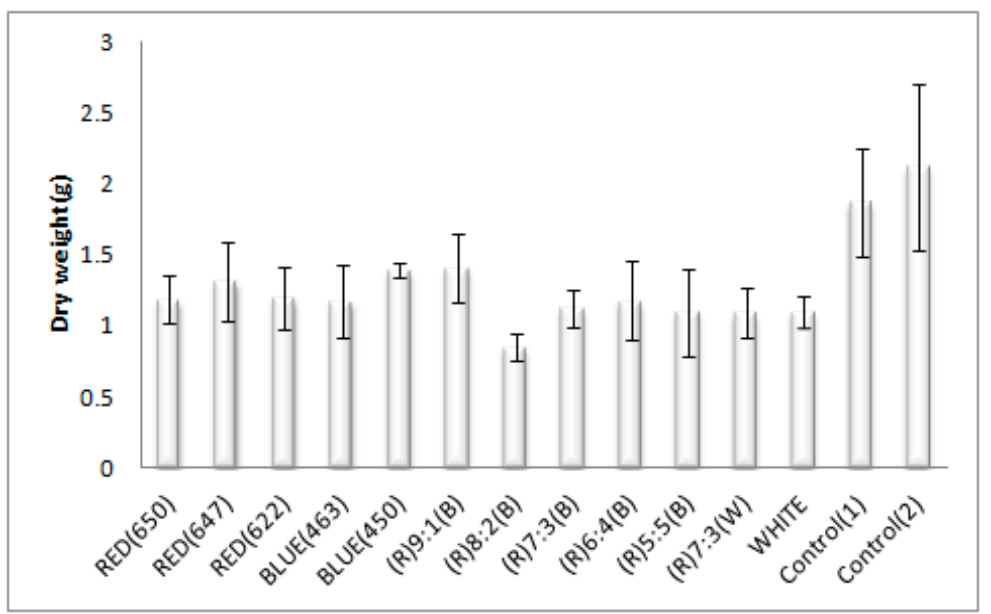

(d) Dry weight of leaf

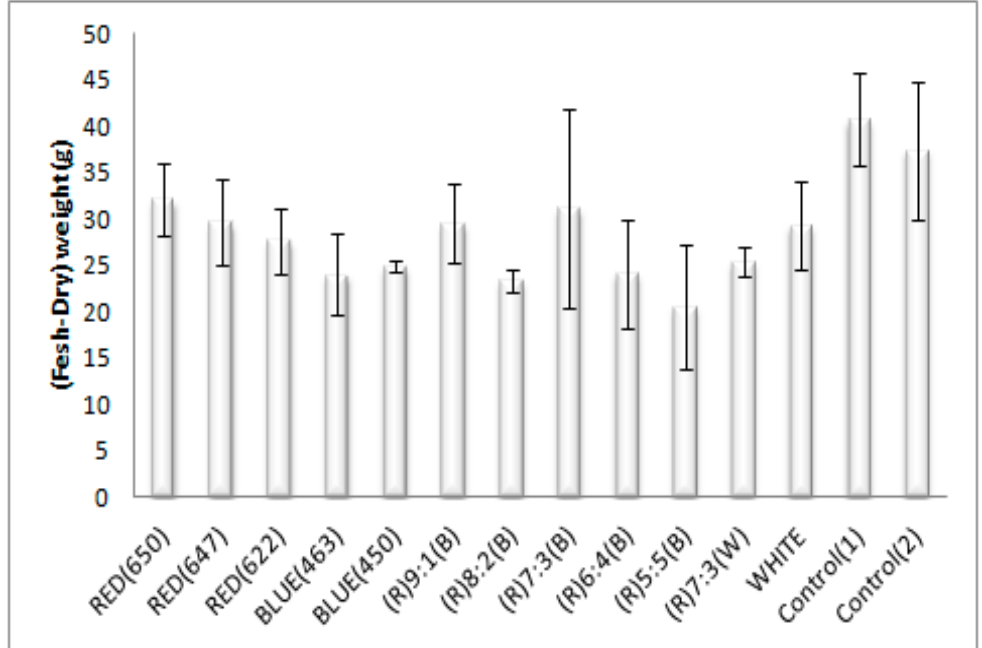

(e) Fresh-Dry weight of leaf

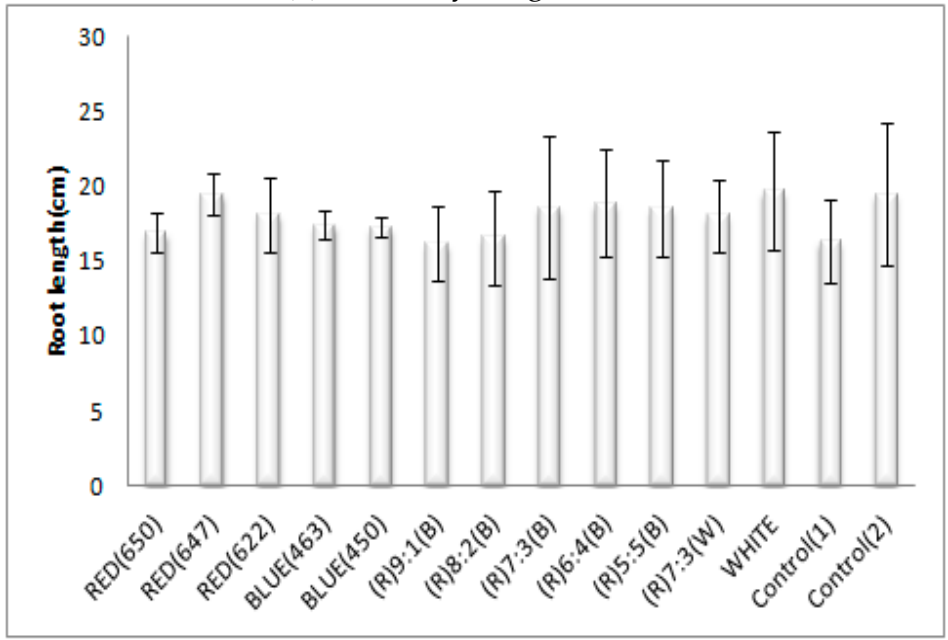

(f) Root length

Figure 17. Cont. 


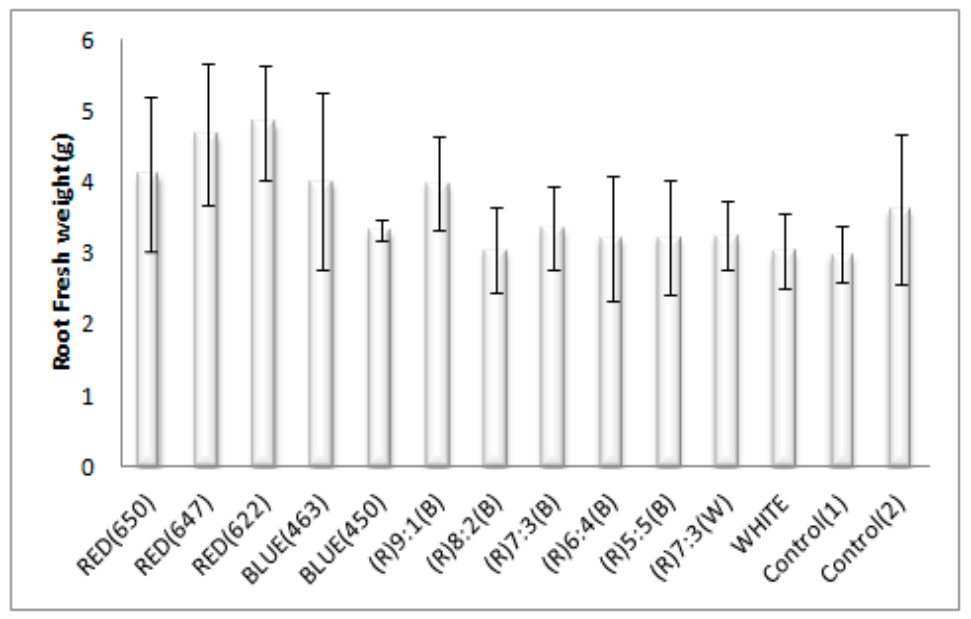

(g) Fresh weight of root

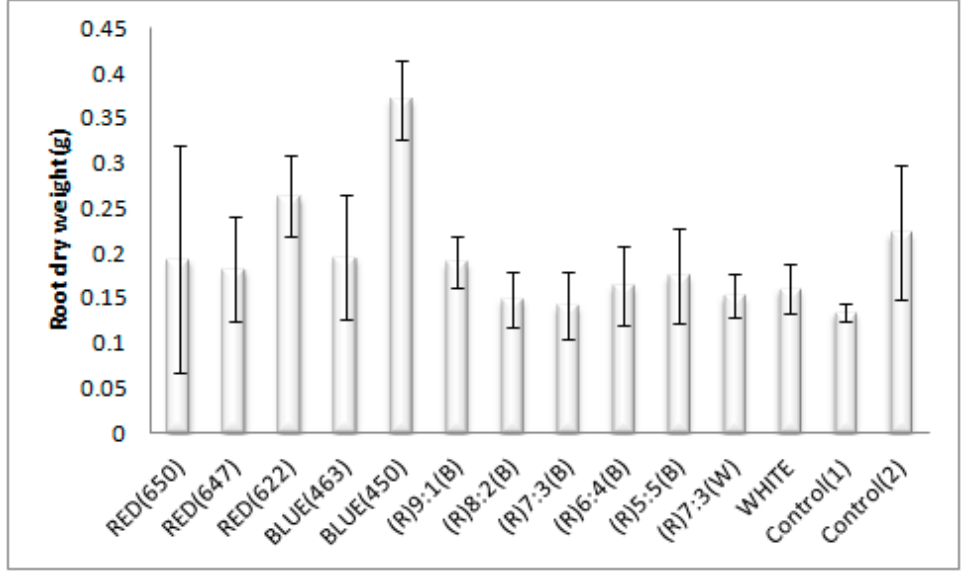

(h) Dry weight of root

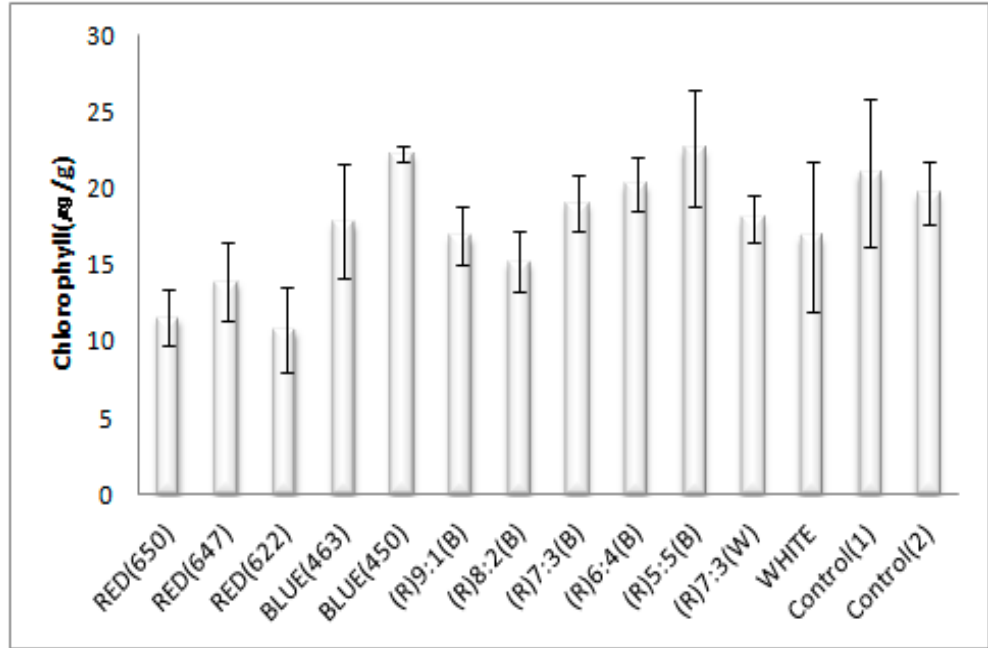

(i) Chlorophyll

Figure 17. Cont. 


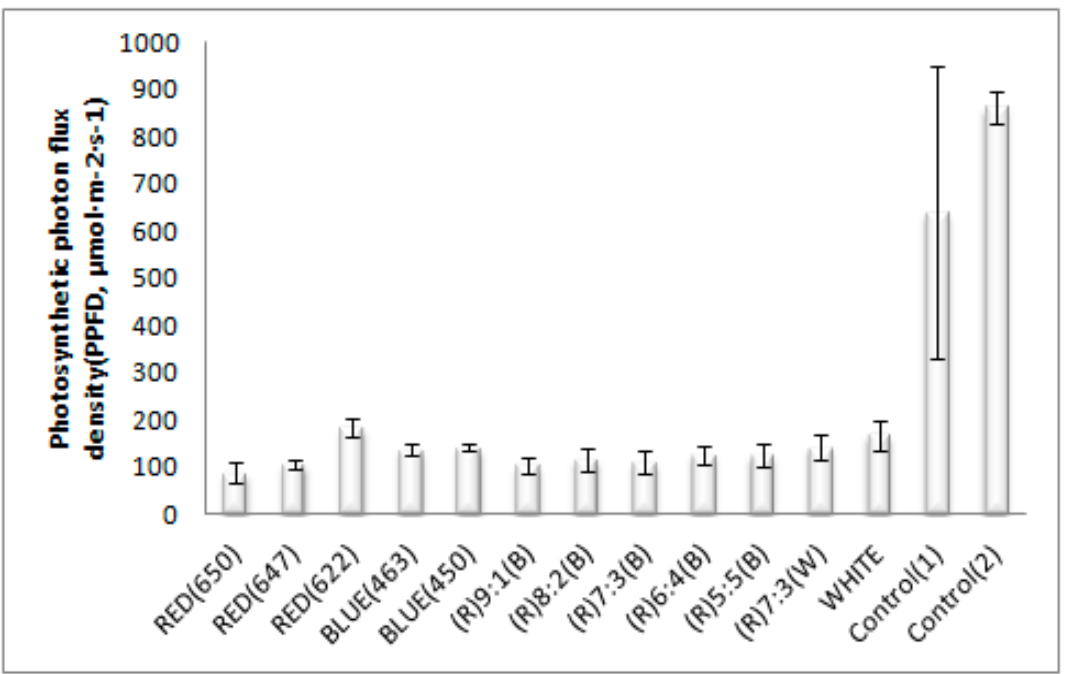

(j) Photosynthetic photon flux density

Figure 17. Growth pattern of lettuce in the plant factory.

Meanwhile, the Kruskal-Wallis test was conducted to examine the significance of the normal distribution patterns in the growth of lettuce, which shows constant trends under various light sources. The analysis data, for which the null hypothesis was not rejected, are shown in Figure 18.

As presented in Table 3, a run test was carried out to investigate if there were any growth patterns in the lettuce.

Table 3. Ranks in the plant factory obtained by Kruskal-Wallis test and significance by Run test.

\begin{tabular}{|c|c|c|c|c|c|c|c|c|c|c|c|c|c|c|c|c|}
\hline \multirow{2}{*}{ Mean Rank } & \multicolumn{3}{|c|}{ RED } & \multicolumn{2}{|c|}{ BLUE } & \multicolumn{5}{|c|}{ (R):(B) } & \multirow[t]{2}{*}{$\begin{array}{l}\text { (R)7: } \\
\text { 3(W) }\end{array}$} & \multirow[t]{2}{*}{ WHITE } & \multicolumn{2}{|c|}{ Control } & \multirow{2}{*}{$\begin{array}{c}\text { Significance } \\
\text { Value by } \\
\text { Kruskal Wallis }\end{array}$} & \multirow{2}{*}{$\begin{array}{c}\text { Significance } \\
\text { Value By Run } \\
\text { Test }\end{array}$} \\
\hline & (650) & (647) & (622) & $(463)$ & (450) & $9: 1$ & $8: 2$ & $7: 3$ & $6: 4$ & $5: 5$ & & & (1) & (2) & & \\
\hline $\begin{array}{l}\text { Number of } \\
\text { leaves }{ }^{* *} \ddagger\end{array}$ & 3 & 1 & 9 & 14 & 13 & 2 & 10 & 4 & 11 & 6 & 8 & 7 & 12 & 5 & 0.001 & 0.016 \\
\hline Fresh weight ${ }^{* *} \ddagger$ & 3 & 5 & 8 & 12 & 10 & 4 & 13 & 7 & 11 & 14 & 9 & 6 & 1 & 2 & 0.001 & 0.002 \\
\hline Dry weight ${ }^{* *} \ddagger$ & 7 & 5 & 8 & 9 & 4 & 3 & 14 & 11 & 6 & 10 & 13 & 12 & 2 & 1 & 0.000 & 0.004 \\
\hline Root length & 4 & 3 & 2 & 6 & 8 & 5 & 13 & 8 & 9 & 10 & 11 & 12 & 14 & 7 & 0.761 & 0.339 \\
\hline Root fresh weight $\ddagger$ & 13 & 12 & 14 & 8 & 2 & 9 & 11 & 6 & 3 & 1 & 7 & 10 & 4 & 5 & 0.025 & 0.810 \\
\hline Root dry weight & 14 & 13 & 4 & 8 & 6 & 13 & 11 & 12 & 9 & 10 & 7 & 5 & 3 & 2 & 0.072 & 0.486 \\
\hline Chlorophyll ${ }^{* *} \ddagger$ & 13 & 12 & 14 & 8 & 2 & 9 & 11 & 6 & 3 & 1 & 7 & 10 & 4 & 5 & 0.000 & 0.004 \\
\hline $\begin{array}{l}\text { Photosynthetic } \\
\text { photon flux } \\
\text { density }\end{array}$ & 14 & 13 & 4 & 8 & 6 & 13 & 11 & 12 & 9 & 10 & 7 & 5 & 3 & 2 & 0.002 & 0.086 \\
\hline
\end{tabular}

${ }^{* *}$ Kruskal Wallis significance $(p<0.05) ; \ddagger$ Run significance $(p<0.05)$.

Through the Kruskal-Wallis test, statistically significant data was obtained in the number of leaves $(p=0.001)$, fresh weight $(p=0.001)$, dry weight $(p=0.000)$, fresh weight of root $(p=0.025)$, chlorophyll $(p=0.000)$, and amount of light $(p=0.002)$, since the null hypotheses of these variables were not rejected, whereas root length $(p=0.761)$ and dry weight of root $(p=0.072)$ did not show statistical significance with the rejected null hypotheses.

Besides, statistical significance via Run test was obtained for the variables number of leaves $(p=0.016)$, fresh weight $(p=0.002)$, dry weight $(p=0.004)$, and chlorophyll $(p=0.004)$, since the null hypotheses were not rejected. In contrast, statistical significance was not obtained for the variables root length $(p=0.339)$, fresh weight of root $(p=0.810)$, dry weight of root $(p=0.486)$, and amount of light $(p=0.086)$ with the rejected null hypotheses. 


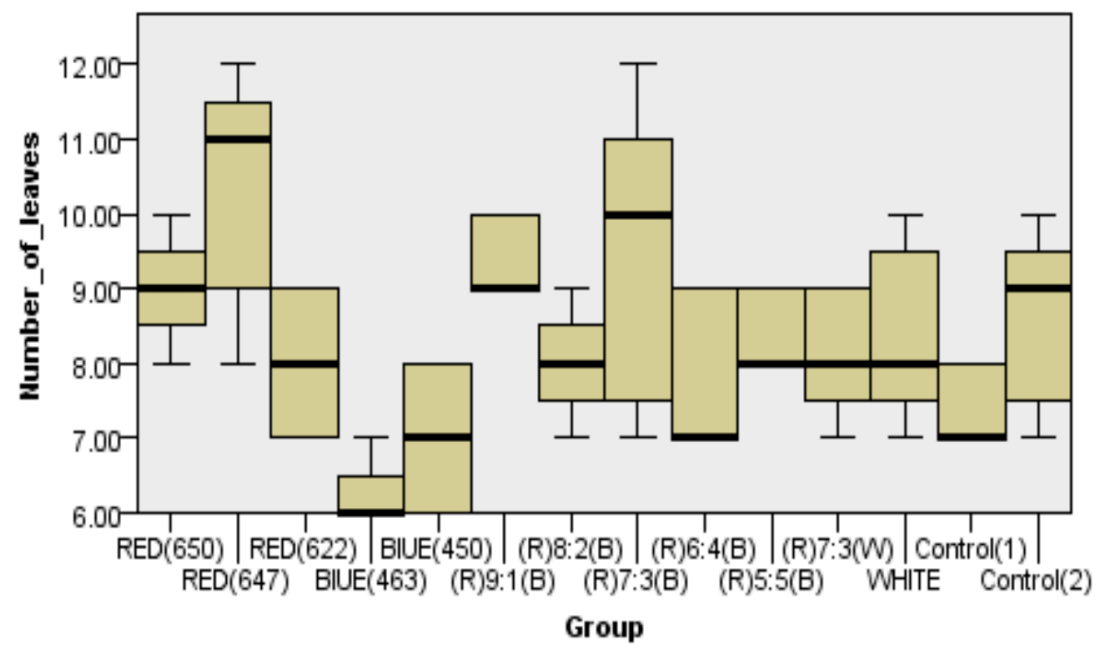

(a) Number of leaves $(p=0.001)$

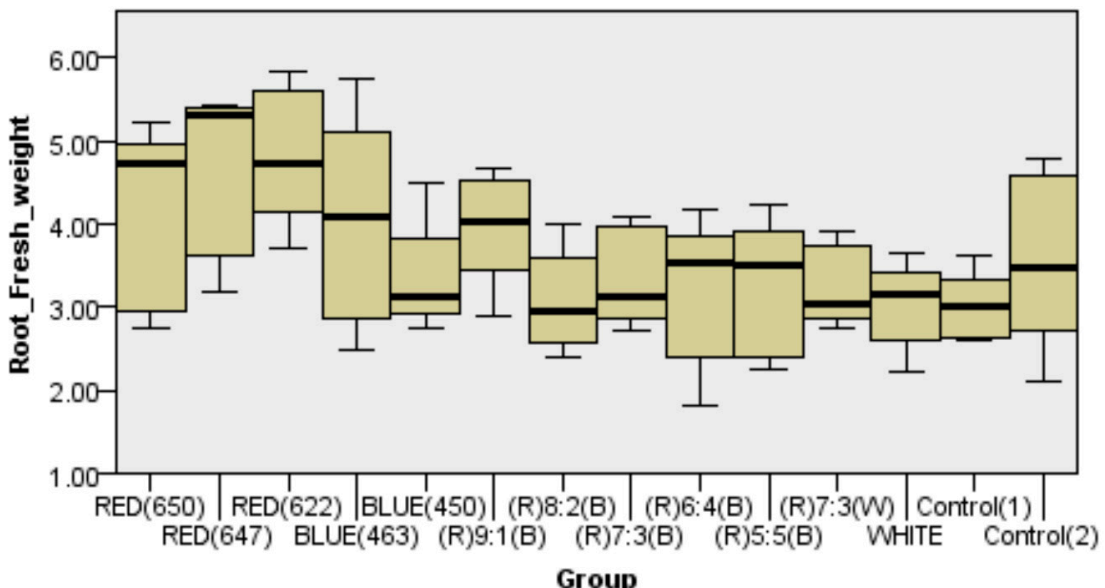

(b) Fresh weight of root $(p=0.025)$

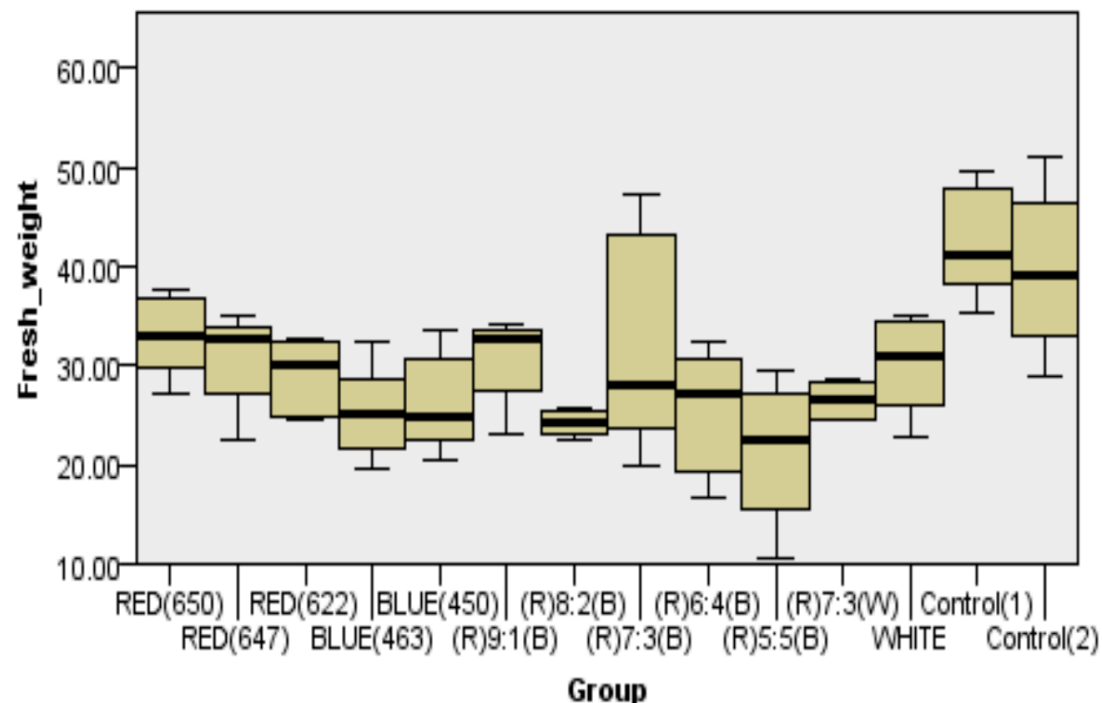

(c) Fresh weight $(p=0.001)$

Figure 18. Cont. 


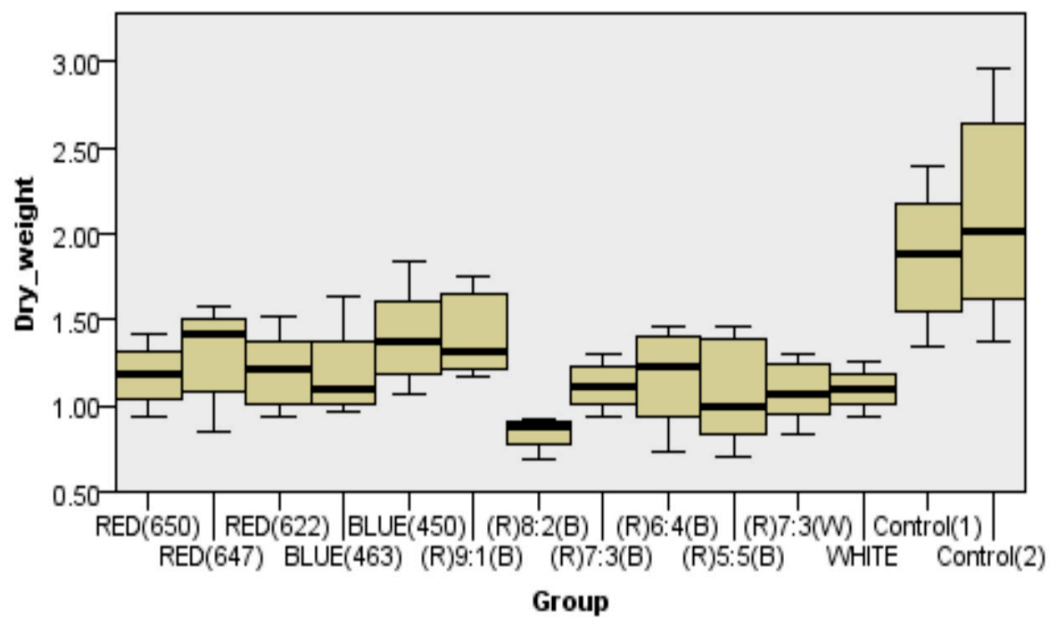

(d) Dry weight $(p=0.000)$

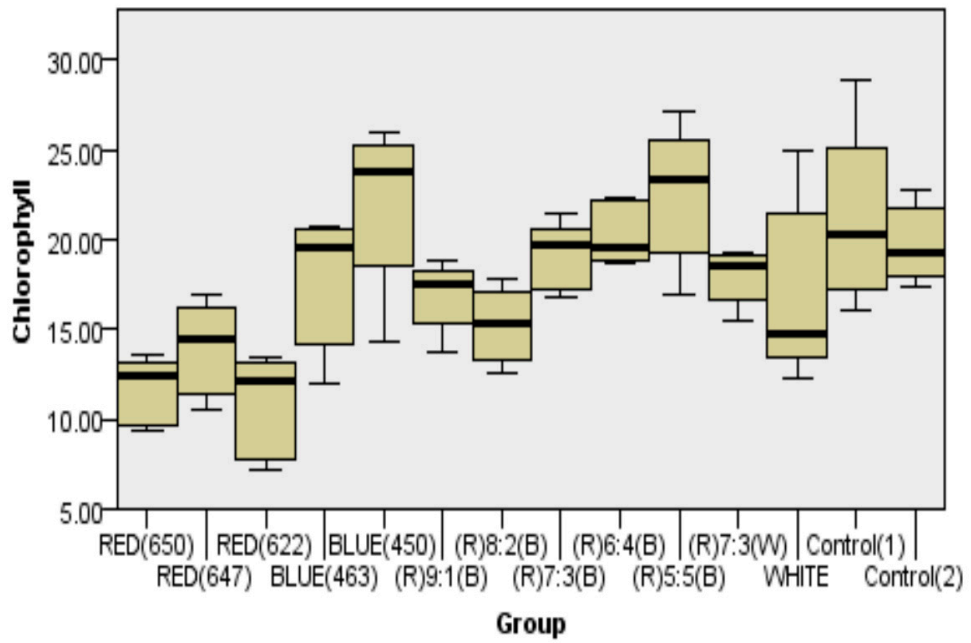

(e) Chlorophyll $(p=0.000)$

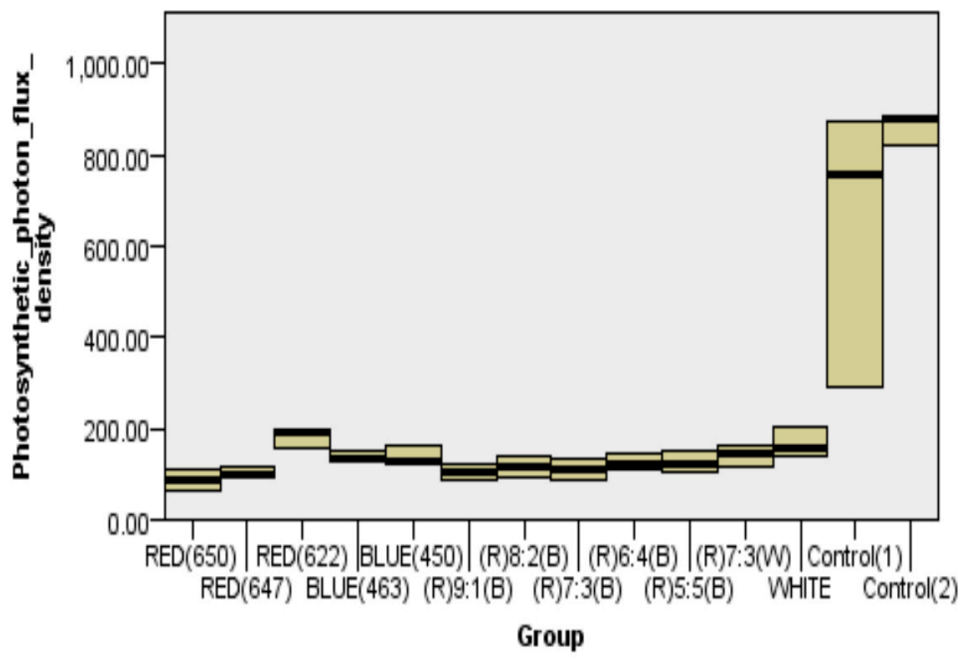

(f) Photosynthetic photon flux density $(p=0.002)$

Figure 18. The analysis data for the plant factory.

\section{Conclusions}

A variety of crop growing technologies are being researched and adopted globally due to the rapid increase in the number of smart farms. This paper deals with the effect of indoor 
environmental conditions and artificial light sources on the growth of lettuce in a plant factory where an experimental lighting system has been used. The spectral characteristics affecting the growth rate were analyzed and an environmental control algorithm was developed along with an imaging system that monitors the growth performances for analysis. With the results obtained from the experiments, a plant operation platform that can adequately control factory environment has been proposed, validating its effectiveness.

The blue wavelength displayed a positive effect on the lettuce leaves, whereas the red wavelength had a positive effect on root growth. On the other hand, lettuce growth improved with an increase in the intensity of light built inside the plant factory. The lettuce with the best performance was found in the control as anticipated. The red color wavelength and white color wavelength showed the best commercial quality, in terms of fresh weight, among the growth indicators, whereas growth was most active under R9:1B and R7:3B within the red and blue combined wavelength. Lettuce growth was affected by air pollutants in the plant factory.

The concentrations of particles and airborne microorganism as indoor air pollutants were analyzed to be around two times higher during the third-phase experiment than those during the first- and second-phase experiments, implying that the growth of lettuce was greatly affected by the generation of air pollutants inside the plant factory.

Author Contributions: Conceptualization, K.-Y.K. and H.-J.K.; data curation, K.-Y.K. and J.-H.H.; formal analysis, K.-Y.K. and H.-J.K.; funding acquisition, H.-J.K.; investigation, K.-Y.K., J.-H.H. and H.J.K.; methodology, K.-Y.K. and J.-H.H.; project administration, H.-J.K.; resources, K.-Y.K., J.-H.H. and H.-J.K.; software, K.-Y.K. and J.-H.H.; supervision, K.-Y.K., J.-H.H. and H.-J.K.; validation, K.-Y.K. and J.-H.H.; visualization, H.-J.K.; writing—original draft, K.-Y.K., J.-H.H. and H.-J.K.; writing-review and editing, H.-J.K. All authors have read and agreed to the published version of the manuscript.

Funding: This work was supported by Korea Institute of Planning and Evaluation for Technology in Food, Agriculture, Forestry and Fisheries (IPET) through Agriculture, Food and Rural Affairs Convergence Technologies Program for Educating Creative Global Leader, funded by Ministry of Agriculture, Food and Rural Affairs (MAFRA) (717001-7).

Institutional Review Board Statement: Not applicable.

Informed Consent Statement: Not applicable.

Data Availability Statement: Not applicable.

Conflicts of Interest: The authors declare no conflict of interest.

$\begin{array}{ll}\text { Abbreviations } \\ \text { CCD } & \text { Charged-Coupled Device } \\ \text { PC } & \text { Personal Computer } \\ \text { ICT } & \text { Information and Communications Technology } \\ \text { IoT } & \text { Internet of Things } \\ \text { CCTV } & \text { Closed-Circuit Television } \\ \text { LED } & \text { Light Emitting Diode } \\ \text { PCB } & \text { Printed Circuit Board } \\ \text { PPDF } & \text { Photosynthetic Photon Flux Density } \\ \text { TSA } & \text { Trypticase Soy Agar } \\ \text { SDAC } & \text { Sabouraud Dextrose Agar + Chloramphenicol } \\ \text { CFU } & \text { Colony Forming Unit }\end{array}$

\section{References}

1. Aksoy, M.A.; Beghin, J.C. Global Agricultural Trade and Developing Countries; World Bank Publications: Washington, DC, USA, 2005.

2. Rosset, P. The Multiple Functions and Benefits of Small Farm Agriculture in the Context of Global Trade Negotiations. Development 2000, 43, 77-82. [CrossRef]

3. Kwit, C.; Moon, H.S.; Warwick, S.I.; Stewart, N. Transgene introgression in crop relatives: Molecular evidence and mitiation stategies. Trends Biotechnol. 2011, 29, 284-293. [CrossRef] [PubMed] 
4. Maria, V.S.; Beltran, D.; Allende, A.; Chacon-vera, E.; Gil, M.I. Elimination by ozone of Shigella in Shredded lettuce and water. Food Microbiol. 2007, 24, 492-499. [CrossRef]

5. Jung, S.D.; Huh, H.W.; Hong, J.H.; Choi, J.S.; Chun, H.S.; Bang, K.H.; Huh, M.K. Genetic diversity and population structure of Kalopanax pictus (Araliaceae). J. Plant Biol. 2003, 46, 255-262. [CrossRef]

6. Amoah, P.; Drechsel, P.; Abaidoo, R.C. Irrigated urban vegetable production in Ghana: Sources of pathogen contamination and health risk elimination. Irrig. Drain. 2005, 54, 49-61. [CrossRef]

7. Purnomohadi, N. Jakarta: Urban agriculture as an alternative strategy to face the economic crisis. City Case Study Jkt. 2005, 13, 453-465.

8. Choi, K.Y.; Lee, Y.B. Effect of Air Temperature on Tipburn Incidence of Butterhead and Leaf Lettuce in a Plant Factory. Korean Soc. Hortic. Sci. 2003, 44, 805-808.

9. Choi, K.Y.; Park, D.K.; Kim, Y.C.; Seo, T.C.; Yun, H.K.; Seo, H.D. Development of Nutrient Solution for Chenopodiaceae Hydroponics by a Rate of Nutrient and Water Uptake and Cation. Korean Soc. Hortic. Sci. 2003, 21, 55.

10. Lee, H.J.; Lee, Y.B.; Bae, J.H. Effect of Root Zone Temperature on the Growth and Quality of Single-Stemmed Rose in Cutted Rose Production Factory. Korean Soc. Bio-Environ. Control. 2004, 13, 266-270.

11. Cantrell, I.C.; Linderman, R.G. Preinoculation of lettuce and onion with VA mycorrhizal fungi reduces deleterious effects of soil salinity. Plant Soil 2001, 33, 269-281. [CrossRef]

12. Francis, G.A.; O'Beirne, D. Effects of the indigenous microflora of minimally processed lettuce on the survival and growth of Listeria innocua. Int. J. Food Sci. Technol. 1998, 33, 477-488. [CrossRef]

13. Guentzel, J.L.; Liang, L.K.; Callan, M.A.; Emmons, S.A.; Dunham, V.L. Reduction of bacteria on spinach, lettuce, and surfaces in food service areas using neutral electrolyzed oxidizing water. Food Microbiol. 2008, 25, 36-41. [CrossRef] [PubMed]

14. King, A.D.; Magnuson, J.A.; TÖRÖK, T.; Goodman, N. Microbial Flora and Storage Quality of Partially Processed Lettuce. J. Food Sci. 1991, 56, 459-461. [CrossRef]

15. Yang, H.; Swem, B.L.; Li, Y. The Effect of pH on Inactivation of Pathogenic Bacteria on Fresh-cut Lettuce by Dipping Treatment with Electrolyzed Water. J. Food Sci. 2003, 68, 1013-1017. [CrossRef]

16. Gravesen, S. Identification and quantitaion of inddor airborne micro-fungi durning 12 months from 44 danish homes. Allergy 1972, 27, 337-354. [CrossRef]

17. Kasprzyk, I.; Morek, M. Airborne fungal spores in urban and rural environments in Poland. Aerobiologia 2006, 22, 169-176. [CrossRef]

18. Şen, B.; Asan, A. Airborne fungi in vegetable growing areas of Edirne, Turkey. Aerobiologia 2001, 17, 69-75. [CrossRef]

19. Collier, G.F.; Tibbitts, T.W. Tipburn of Lettuce Horticultural Reviews; John Wiley \& Sons, Inc.: Hoboken, NJ, USA, $1982 ;$ pp. $49-65$.

20. Pastuszka, J.S.; Kyaw, T.P.U.; Lis, D.O.; Wlazło, A.; Ulfig, K. Bacterial and fungal aerosol in indoor environment in Upper Silesia, Poland. Atmos. Environ. 2000, 34, 3833-3842. [CrossRef]

21. Wu, P.C.; Su, H.J.; Lin, C.Y. Characteristics of indoor and outdoor airborne fungi at suburban and urban homes in two seasons. Sci. Total Environ. 2000, 253, 111-118. [CrossRef]

22. Park, H.S.; Chung, D.H.; Joo, Y.J. Survey of airborne pollens in Seoul, Korea. J. Korean Med. Sci. 1994, 9, 42-46. [CrossRef] [PubMed]

23. Allende, A.; Martínez, B.; Selma, V.; Gil, M.I.; Suárez, J.E.; Rodríguez, A. Growth and bacteriocin production by lactic acid bacteria in vegetable broth and their effectiveness at reducing Listeria monocytogenes in vitro and in fresh-cut lettuce. Food Microbiol. 2007, 24, 759-766. [CrossRef] [PubMed]

24. Koseki, S.; Isobe, S. Prediction of pathogen growth on iceberg lettuce under real temperature history during distribution from farm to table. Int. J. Food Microbiol. 2005, 104, 239-248. [CrossRef] [PubMed]

25. Lee, J.J.; Park, R.D.; Kim, Y.W.; Shim, J.H.; Chae, D.H.; Rim, Y.S. Effect of food waste compost on microbial population, soil enzyme activity and lettuce growth. Bioresour. Technol. 2004, 93, 21-28. [CrossRef] [PubMed]

26. Kozai, T. Propagation, grafting and transplant production in closed systems with artificial lighting for commercialization in Japan. Propag. Ornam. Plant. 2007, 7, 145-149.

27. Kim, I.S.; Zhang, C.; Kang, H.M.; Mackay, B. Control of stretching of cucumber and tomato plug seedlings using supplemental light. Hort. Envior. Biotechnol. 2008, 49, 287-292.

28. Ijaz, F.; Siddiqui, A.A.; Im, B.K.; Lee, C. Remote management and control system for LED based plant factory using ZigBee and Internet. In Proceedings of the 2012 14th international conference on advanced communication technology (ICACT), Phoenix Park, PyeongChang, Korea, 19-22 February 2012; pp. 942-946.

29. Olle, M.; Viršile, A. The effects of light-emitting diode lighting on greenhouse plant growth and quality. Agric. Food Sci. 2013, 22, 223-234. [CrossRef]

30. Watanabe, H. Light-controlled plant cultivation system in Japan-development of a vegetable factory using LEDs as a light source for plants. In Proceedings of the 6th International Symposium on Light in Horticulture, Tsukuba, Japan, 15-19 November 2009; pp. 37-44.

31. Goto, E. Plant production in a closed plant factory with artificial lighting. In Proceedings of the 7th International Symposium on Light in Horticultural Systems, Wageningen, The Netherlands, 15-18 October 2012; Volume 956, pp. 37-49.

32. Barrett, G.E.; Alexander, P.D.; Robinson, J.S.; Bragg, N.C. Achieving environmentally sustainable growing media for soilless plant cultivation systems-A review. Sci. Hortic. 2016, 212, 220-234. [CrossRef] 
33. Schmilewski, G. The role of peat in assuring the quality of growing media. Mires Peat 2008, 3, 1-8.

34. Carlile, W.R.; Cattivello, C.; Zaccheo, P. Organic growing media: Constituents and properties. Vadose Zone J. $2015,14,1-13$. [CrossRef]

35. Alexander, P.D.; Bragg, N.C.; Meade, R.; Padelopoulos, G.; Watts, O. Peat in horticulture and conservation: The UK response to a changing world. Mires Peat 2008, 3, 1-10.

36. Cleary, J.; Roulet, N.T.; Moore, T.R. Greenhouse gas emissions from Canadian peat extraction, 1990-2000: A life-cycle analysis. AMBIO J. Hum. Environ. 2005, 34, 456-461. [CrossRef]

37. Carlile, B.; Coules, A. Towards sustainability in growing media. In Proceedings of the International Symposium on Growing Media, Composting and Substrate Analysis, Barcelona, Spain, 17-21 October 2011; Volume 1013, pp. 341-349.

38. Kern, J.; Tammeorg, P.; Shanskiy, M.; Sakrabani, R.; Knicker, H.; Kammann, C.; Tuhkanen, E.M.; Smidt, G.; Prasad, M.; Tiilikkala, K.; et al. Synergistic use of peat and charred material in growing media-An option to reduce the pressure on peatlands? J. Environ. Eng. Landsc. Manag. 2017, 25, 160-174. [CrossRef]

39. Chrysargyris, A.; Prasad, M.; Kavanagh, A.; Tzortzakis, N. Biochar type, ratio, and nutrient levels in growing media affects seedling production and plant performance. Agronomy 2020, 10, 1421. [CrossRef]

40. Tüzel, Y.; Ekinci, K.; Öztekin, G.B.; Erdal, I.; Varol, N.; Merken, Ö. Utilization of olive oil processing waste composts in organic tomato seedling production. Agronomy 2020, 10, 797. [CrossRef]

41. Gohardoust, M.R.; Bar-Tal, A.; Effati, M.; Tuller, M. Characterization of Physicochemical and hydraulic properties of organic and mineral soilless culture substrates and mixtures. Agronomy 2020, 10, 1403. [CrossRef]

42. Huang, L.; Gu, M.; Yu, P.; Zhou, C.; Liu, X. Biochar and vermicompost amendments affect substrate properties and plant growth of basil and tomato. Agronomy 2020, 10, 224. [CrossRef]

43. Blok, C. Growing Media for Food and Quality of Life in the Period 2020-2050. Acta Hortic. 2020. In Press. Available online: https:/ / peatlands.org/document/growing-media-blok-2018/ (accessed on 31 March 2021).

44. Van Gerrewey, T.; Vandecruys, M.; Ameloot, N.; Perneel, M.; van Labeke, M.C.; Boon, N.; Geelen, D. Microbe-Plant Growing Media Interactions Modulate the Effectiveness of Bacterial Amendments on Lettuce Performance Inside a Plant Factory with Artificial Lighting. Agronomy 2020, 10, 1456. [CrossRef]

45. Available online: https:// cnews.smartfn.co.kr/view.php?ud=20190930112453350227695a3dd0_46 (accessed on 31 March 2021).

46. Korea Vocational College of Food and Agriculture. Available online: https://m.blog.naver.com/supersizeher/220564559027 (accessed on 31 March 2021).

47. Available online: https://www.itmedia.co.jp/smartjapan/articles/1405/27/news084.html (accessed on 31 March 2021). 